LANGUAGE ACQUISITION, 14(1), 31-73

Copyright @ 2007, Lawrence Erlbaum Associates, Inc.

\title{
On the "Vulnerability" of Syntactic Domains in Swedish and German
}

\author{
Ute Bohnacker \\ Uppsala University and \\ Lund University
}

\begin{abstract}
This article investigates the L2 acquisition of clausal syntax in postpuberty learners of German and Swedish regarding V2, VP headedness, and verb particle constructions. The learner data are tested against L2 theories according to which lower structural projections (VP) are acquired before higher functional projections (IP, $\mathrm{CP}$ ), VP syntax is unproblematic (invulnerable), but where grammatical operations related to the topmost level of syntactic structure (CP) are acquired late (e.g., Platzack's (2001) vulnerable C-domain). It is shown that such theories do not hold water: Native speakers of Swedish learning German and native speakers of German learning Swedish both master V2 from early on. At the same time, these learners exhibit a nontargetlike syntax at lower structural levels: residual VO in the case of the Swedish-L1 learners of German, and persistent nontarget transitive verb particle constructions in the German-L1 learners of Swedish. I argue that these findings are best explained by assuming full transfer of L1 syntax (e.g., Schwartz and Sprouse (1996)).
\end{abstract}

\section{INTRODUCTION}

Many theories of developmental syntax build on the assumption that acquisition proceeds from the bottom up. In generative terms, this means that lower structural projections are acquired before higher ones and that lexical categories and projections are targetlike before functional projections are. These assumptions have been made for both first (L1) and second (L2) and foreign language acquisition (e.g., Clahsen (1990/1991), Clahsen, Penke, and Parodi (1993/1994), Hawkins (2001), Radford (1988a), Vainikka and Young-Scholten (1994; 1996a;

Correspondence should be sent to Ute Bohnacker, Centre for Languages and Literature, Lund University, Box 201, SE-22100, Lund, Sweden. E-mail: ute.bohnacker@nordlund.lu.se 
1996b)), and on some approaches, learners only have to grapple with the acquisition of the topmost levels of syntactic structure (e.g., Bhatt and Hancin-Bhatt (2002), Hulk and Müller (2000), Platzack (1996; 2001)). For instance, Platzack, in his much-cited 2001 article "The Vulnerable C-domain," examined the acquisition of Swedish and German and argued that the CP represents a "vulnerable domain," where grammatical operations related to this clause level are acquired imperfectly and comparatively late, and elements associated with the $\mathrm{CP}$ tend to be omitted. Platzack contrasted the vulnerability of the C-domain with the "invulnerability" of lower structural domains (VP, IP), which are said to be acquired effortlessly and early by all—child and adult—language learners.

This article challenges these claims on the basis of quantified learner data from Swedish/German and German/Swedish. The findings of a recent study of adolescent and adult learners of German by Bohnacker $(2005 ; 2006 \mathrm{~b})$ are summarized, and a new study of adult learners of Swedish is presented in detail. In these learners' interlanguages, syntactic operations at high clause-structural levels, in particular Verb Second (finite verb in second position), are targetlike from early on. At the same time, the learners exhibit a nontargetlike syntax at lower structural levels. The native speakers of German learning Swedish have word order problems with transitive verb particle constructions that persist for many years; the native speakers of Swedish learning German have residual problems with object and nonfinite verb ordering (OV). I show that such findings are best explained by assuming transfer of L1 syntax at all structural levels, even for advanced learners. These points hold irrespective of which formal syntactic apparatus is chosen to capture (Swedish and German) clause structure and the operations that lead to a certain word order, because linguists are generally in agreement that V2 involves a higher clause-structural domain than do particle verbs and $\mathrm{VO} / \mathrm{OV}$.

I argue that theories that postulate the existence of universally vulnerable, or universally invulnerable, syntactic domains are misguided and should be abandoned. Rather, we should look to transfer-based theories (e.g., Schwartz and Sprouse $(1994 ; 1996))$ to predict and describe the developmental paths of nonnative language learners.

The article proceeds as follows. Section 2 outlines and contrasts the syntactic properties of German and Swedish V2, OV/VO, and verb particle constructions (VPCs). Section 3 presents some of the proposals that have been made regarding the L2 acquisition of these areas of clausal syntax, including (in)vulnerable domains. Section 4 summarizes Bohnacker's (2005) findings for the acquisition of finite and nonfinite verb placement by native speakers of Swedish learning German. In section 5.1, background information on a new study of native speakers of German learning Swedish is provided (informants, data collection, method). Sections 5.2, 5.3, and 5.4 investigate the L2 Swedish data quantitatively and qualitatively with regard to finite verb placement (V2), VP headedness, and word order in VPCs. This is followed by a discussion of the learnability of VPC 
syntax and of how the informants' acquisitional path(s) may best be captured by current L2 theories. Section 6 contains concluding remarks.

\section{SYNTACTIC BACKGROUND}

\subsection{Verb Second}

As is well known, main clauses in both Swedish and German require the second constituent to be the finite verb (V2) (cf. e.g., Teleman, Hellberg, and Andersson (1999b, 10-13), Zifonun, Hoffman, and Strecker $(1997,1500))$. This means that for non-subject-initial main clauses, so-called inversion of the subject and the verb (XVS) is required, whereas V3 is (generally) ungrammatical, as shown in $(1 \mathrm{~b} / 1 \mathrm{c})$.

\section{(1) Swedish}

SVO a. jag visar er diagrammet nu.

I show you chart-the now

'I'll show you the chart now.'

XVS b. nu visar jag er diagrammet.

${ }^{*} \mathrm{XSV}$ c. ${ }^{*}$ nu jag visar er diagrammet.

German

SVO $a^{\prime}$. ich zeige euch jetzt das Diagramm.

I show you now the chart

XVS $b^{\prime}$. jetzt zeige ich euch das Diagramm.

*XSV $\mathrm{c}^{\prime} .{ }^{*}$ jetzt ich zeige euch das Diagramm.

Though SVX is often said to be the most frequent word order (1a), inversion is very common too (1b). In fact, the first position can be occupied by virtually any constituent, phrasal or clausal, argumental or nonargumental, phonologically heavy or light (including unstressed object pronouns), and with any semantic function (some modal particles excluded). ${ }^{1}$

Generative grammars typically describe V2 as a two-step process, a syntactic double-movement transformation: leftward movement of the finite verb to a functional-head position on the left sentence periphery, creating a V1 clause, plus movement of a constituent into the specifier position of that Functional

\footnotetext{
${ }^{1}$ One Language Acquisition reviewer wonders whether my description of the set of items that can occur in initial position is somewhat too generous, because unstressed object pronouns have been claimed to be impossible sentence-initially. However, I believe this claim to be a myth. Unstressed object pronouns in initial position are regularly attested in Swedish and in many varieties of German, including my own. Despite previous claims in the literature to the contrary (e.g., Cardinaletti and Starke (1995), Travis (1984)), standard German accusative es (it) can also occur in initial position, as shown by the sentences in (i)-(iii), often cited in German-speaking linguistics circles (cf. Gärtner
} 
Projection. In Government and Binding models, this projection is commonly identified as CP (e.g., Grewendorf (1988, 64-67), but see Brandt, Reis, Rosengren, and Zimmermann (1992) for an alternative). Clause-initial subjects and nonsubjects-which occupy the same linear position (i.e., jag/ich in (1a) and $n u / j e t z t$ in (1b)) — occupy the same hierarchical position in symmetric V2 analyses (e.g., Grewendorf, Hamm, and Sternefeld (1987), Schwartz and Vikner (1989)), though they do not on an asymmetric V2 analysis, where subject-initial clauses are smaller than nonsubject initial ones (e.g., Travis (1984; 1991), Zwart (1993)). With the breaking-up of the CP domain into several functional projections in GB and Minimalist models, suggestions of where to locate that first constituent and the verb have multiplied. ${ }^{2}$ I am very brief here and concentrate on the linear order of constituents (SVX, V1, V2, V3, etc.), abstracting away from analytical questions concerning the structural account of this linear order, as the findings to be reported do not hinge on any specific syntactic analysis.

Swedish and German syntax are largely the same as regards V2, except that Swedish allows some pockets of V3, as has been shown in detail by Bohnacker (2004; 2005). Unlike German, V3 is grammatical in Swedish main clauses (i) with the high-frequency clause-initial consequential connective så 'so' (2), (ii) with left-dislocated adverbials followed by resumptive $s a ̊$ 'so' (3), (iii) with

and Steinbach (2000)). It is easy to make up new examples, such as (iv).

(i) Ihr Geld ist ja nicht weg, meine Damen und Herren. Es haben jetzt your money is well not gone, my ladies and gentlemen it-ACC have now nur andere. only others 'Well, your money isn't gone, ladies and gentlemen. It's just owned by someone else.'

(ii) Das wissen nicht nur die Experten, es wissen auch die Laien. this know not only the experts, it-ACC know also the laypeople 'Not only experts know that, laypeople know it too.'

(iii) Wie ist denn das Kind an das Buch gekommen? Es hat ihm jemand geschenkt. how is then the child to the book come it-ACC has it-DAT someone given 'How did the child get the book? Someone gave it to her/him.'

(iv) Das hier kannste streichen. Es hat sowieso nie wer verstanden. this here can-you delete it has anyway never anyone understood 'You can delete that. Nobody ever understood it anyway.'

\footnotetext{
${ }^{2}$ Certain analyses move the verb out of the VP directly into $\mathrm{C}$; others do so via one or more head positions in the IP domain. The existence and headedness of IP (TP, AgrP, etc.) in German is a matter of debate (cf. e.g., Haider (1993), who argued against IP in German and Scandinavian). Many proposals exist about what might motivate and drive V2, for example, a spec-head relationship, some (e.g., tense/finiteness) feature of the verb or on the position it moves to, and/or some (e.g., topic/focus) feature of the XP constituent or the left-peripheral position it moves to. The wide variety of elements that can occur preverbally-including nonreferential arguments (like the subjects of weather verbs), all types of adverbials and V-projections-makes it difficult, I believe, to argue that they have an abstract grammatical feature in common (cf. Haider (1993, 69-70)).
} 
certain "focalizing" adverbs such as bara 'only' and kanske 'maybe' (4), and (iv) marginally in a few other contexts that are not illustrated here.

(2) Swe. maten där var förfärlig, ...

food-the there was dreadful

a. ... så dit går jag aldrig igen.

so thither go I never again

b. ... så jag ska aldrig gå dit igen.

so I will never go thither again

'The food there was dreadful, so I'll never go back there again.'

(3) Swe. sen så gick hon.

then so went she

'Then she left.'

(4) Swe. a. hon kanske vill gå dit.

she maybe wants go thither

$a^{\prime}$. kanske hon vill gå dit.

' $\{$ She maybe/Maybe she $\}$ wants to go there.'

b. jag bara kollar.

I just check

'I'm just checking.'

Except in such cases, it should be easy for Swedes and Germans to parse and produce V2 main clauses in the other language, by making use of their L1V2 syntax (positive transfer). However, on the assumption that there is no such transfer and/or that higher syntactic domains (CP) are universally vulnerable, acquiring V2 in the other language should be a problem.

\section{2. $\mathrm{VO} / \mathrm{OV}$}

German non-finite utterances require the verb or verbal element(s) to be in final position. Because of this fact, German is regarded as an OV language (at the relevant level of abstraction), and generative grammar standardly holds German to have a head-final VP. German finite clauses also have a requirement on verbs to be in final position, but in main clauses this only holds for the nonfinite verbal elements of complex verbs, such as infinitives, participles, and particles of separable prefix verbs (5a). The positioning of these verbal elements is regarded as further evidence of the German VP being head-final. In Swedish, the nonfinite verbal element(s) appear not in final position but to the left of the complement(s), cf. $\left(5 \mathrm{~b} / \mathrm{b}^{\prime}\right)$. Swedish is therefore regarded as a VO language with a head-initial VP. This surface difference in nonfinite verb placement between the two languages obtains irrespectively of how OV/VO is syntactically formalized, 
that is, whether it is truly a difference in "headedness" of VP or whether that is just shorthand for a more intricate syntactic structure (e.g., Kayne (1994), Platzack (1998)).

(5) Ger. a. ich werde euch das Diagramm zeigen. (OV)

I will you the chart show

$\mathrm{a}^{\prime} .{ }^{*}$ ich werde zeigen euch das Diagramm.

Swe. b. jag ska visa er diagrammet. (VO)

I will show you chart-the

'I'll show you the chart.'

$\mathrm{b}^{\prime} .{ }^{*}$ jag ska er diagrammet visa.

L1 transfer theories predict that native speakers of Swedish learning German will produce nontarget $\mathrm{VO}$ orders and that native speakers of German learning Swedish will produce nontarget OV, at least initially so (negative transfer). By contrast, approaches that envisage universal developmental routes and/or universal vulnerable (higher) domains assume that such nontarget orders do not occur-and they should certainly be much less of a problem than acquiring V2 finite verb placement.

\subsection{Verb Particle Constructions}

There is another difference between German and Swedish syntax regarding nonfinite verbal elements and the V-domain, which I dwell on somewhat longer, as it has not received much attention in the L2 acquisition literature: word order with transitive VPCs, also known as phrasal verbs or particle verbs. This construction consists of three components - a verb, a so-called particle (Prt), and a nominal (DP) - and is found in a continuous and discontinuous form in the Germanic languages, for example, put down the cat, put the cat down (in the sense of 'lower the cat,' 'put the cat to death due to age/illness,' etc.). The particle in this construction is an accented element (formally and semantically often but not always related to a preposition) that is in close relationship with a verb. In Swedish the particle precedes the nominal, as illustrated in (6a); in German it is the reverse $(6 b){ }^{3}$

(6) Swe. a. nu tar jag bort diagrammet.

now take I away chart-the

'I'll take the chart off now.'

Ger. b. jetzt nehme ich das Diagramm weg. now take I the chart away

\footnotetext{
${ }^{3}$ There are also many intransitive particle verbs that only consist of a verb and a particle and no nominal (e.g., take off, fall behind), but these are not under investigation here.
} 
The verb and particle are in a close relationship and behave as a prosodic unit, and often also as a syntactic and semantic unit on various tests (cf. Norén (1996, 10-17), Teleman $(1974,66-70))$, but in other ways the particle also behaves like a constituent in its own right. ${ }^{4}$

It is an unresolved issue whether verb particle constructions should be treated as one group and receive a unified syntactic representation (e.g., Jackendoff (2002)) or whether they should be divided into subtypes (e.g., Sawyer (2001), Wurmbrand (2000)). This is because sometimes their semantics is transparent and compositional, that is, the meaning of the VPC is determined by the meaning of its parts (e.g., put + down $=$ 'lower') but sometimes noncompositional, idiomatic, and idiosyncratic (e.g., put down = 'put to death,' 'humiliate,' etc.). It is not always easy to draw a line between transparent and (semi-)idiomatic meanings. Moreover, not all VPCs behave quite alike syntactically; for instance, particles sometimes behave more like heads, sometimes more like phrases (which can be topicalized or modified, e.g., put the cat (partly) down). For an overview see, for example, Haegeman and Guéron (1999, 249-267) and Jackendoff (2002). Here I do not take a stance on whether transparent and idiomatic VPCs warrant different structural representations.

2.3.1. Swedish VPCs. It is received wisdom that Swedish verb particle constructions only allow the order verb-particle-DP (e.g., Ejerhed (1979), Teleman $(1974,67))$, as illustrated in (7).

(7) Swe. a. (att) ta bort $\{$ diagrammet/det $\}$

(to) take away chart-the/it

'to take $\{$ the chart/it $\}$ off'

$\mathrm{a}^{\prime} .{ }^{*}$ att ta $\{$ diagrammet/det $\}$ bort (nonfinite VPC)

b. nu ska jag ta bort \{diagrammet/det\}. now will I take away chart-the/it 'I'll take \{the chart/it $\}$ off now.'

$\mathrm{b}^{\prime} .{ }^{*}$ nu ska jag ta $\{$ diagrammet/det\} bort. (finite clause, nonfinite VPC)

c. nu har jag tagit bort diagrammet/det. now have I taken away \{chart-the/it\} 'I've taken the chart/it off now.'

$\mathrm{c}^{\prime} .{ }^{*}$ nu har jag tagit $\{$ diagrammet/det $\}$ bort. (finite clause, nonfinite VPC)

\footnotetext{
${ }^{4}$ I use the term particle for expository purposes only and remain agnostic as to whether there is a category Particle or whether particles can be subsumed under prepositions, adverbs, and so on. See, e.g., Emonds (1972, 546-555) and Lüdeling (1999) for discussion.
} 


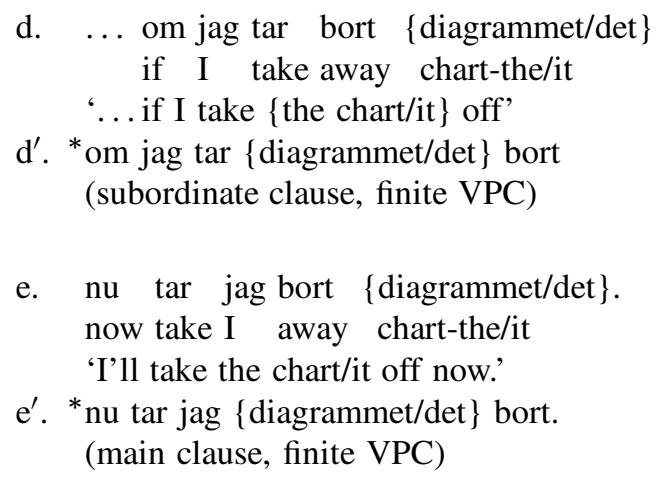

Swedish does not allow both Prt-DP and DP-Prt in VPCs as, for example, English and Norwegian. In Swedish, Prt-DP order obtains irrespective of whether the verb is nonfinite or finite (7a-e), irrespective of whether the verb has been separated from Prt and DP by leftward verb (V2) movement (7e), and irrespective of whether the nominal in question is a nonpronominal DP (e.g., diagrammet 'the chart') or a pronoun (det 'it')..$^{5,6}$

\footnotetext{
${ }^{5}$ According to Vinka (1999), DP-Prt order in semantically transparent VPCs is acceptable when the DP is a deaccented (weak) pronoun, alongside the more usual Prt-DP order. However, the native speakers of Swedish I have consulted clearly reject such pn-Prt in out-of-the-blue contexts (i a). (Vinka $(1999,571)$ did mention that native speakers do not always share his judgments.) I have found one informant who sometimes accepts deaccented pn-Prt orders but only in carefully construed contexts with a particular intonation: if the object pronoun is deaccented, if the particle is heavily (emphatically or contrastively) stressed, and if it is followed by a deaccented constituent (i a $\mathrm{a}^{\prime}$ ). Because none of these adjustments are necessary for Prt-DP order (cf. (i b)), I disregard (i $\mathrm{a}^{\prime}$ ) here.
}

(i) a. * du måste sätta den på!

$\mathrm{a}^{\prime}$. ? du måste sätta den 'på (först)!

b. du måste sätta $\{$ på/'på $\}$ den (först)!

you must switch on/ON it first

'You've got to switch it on (first)!'

${ }^{6}$ Linear DP-Prt order also arises in non-subject-initial main clauses when (what is commonly considered to be) the underlying object DP is promoted to subject, such as in synthetic passives (i) and unaccusatives (ii).

(i) nu ta-s $\quad$ diagrammet/det $\}$ bort.

now take-PASS chart-the/it away

'Now $\{$ the chart/it $\}$ is being taken off.'

(ii) sen kom \{diagrammet/det $\}$ bort.

then came chart-the/it away

'Then $\{$ the chart/it $\}$ disappeared.' 
There are, however, some exceptions to Swedish always being V-Prt-DP. First, some highly idiomatic, nonproductive VPCs occur with V-DP-Prt order (e.g., lägga manken till lay withers to 'put \{one's back/all one's strength\} into something'). Second, and perhaps more important, VPCs that involve a (deaccented) reflexive pronoun fall into three groups. Though many only allow the (usual) V-Prt-DP reflexive $_{\text {order (8a), some allow only V-DP }}$ reflexive-Prt (8b), and a few allow both V-Prt-DP ${ }_{\text {reflexive }}$ and V-DP reflexive Prt (8c); see, for example, Hulthén (1947, 163-167), Teleman, Hellberg, and Andersson (1999a, 424-425). Which type of VPC it is cannot be predicted from the choice of verb or particle.

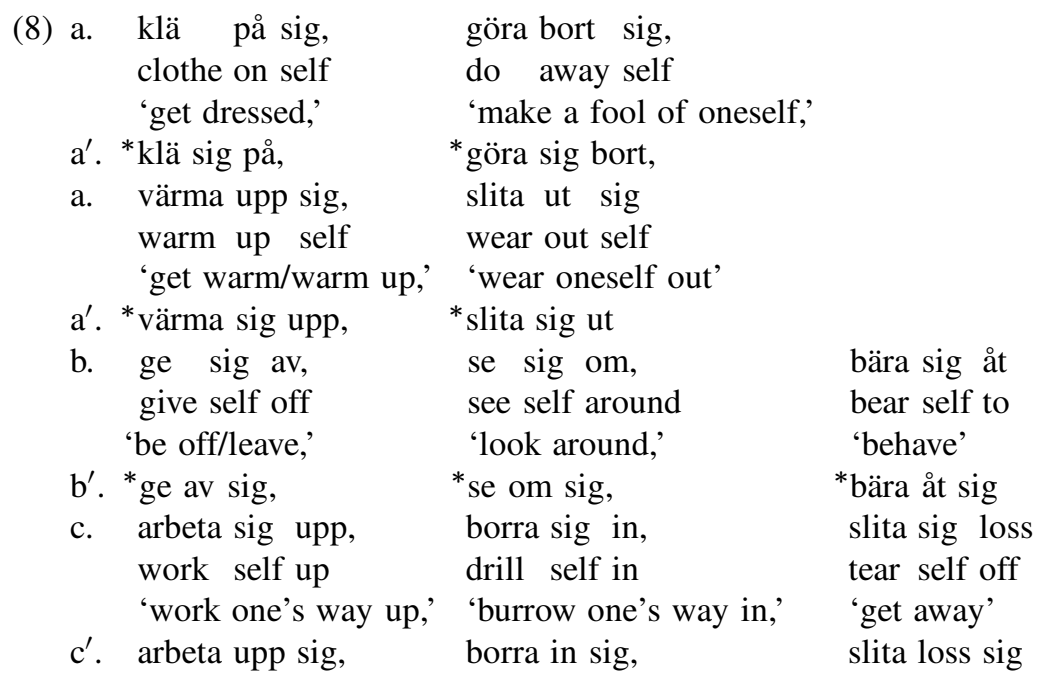

The particle in Swedish VPCs must be stressed, whereas the verb and the nominal are deaccented (e.g., Norén (1996, 11-12)). Sometimes, the string VP(rt)-DP can be a VPC (9a) or a verb plus PP-adjunct (9b), but although a VPC-particle is always stressed, the preposition in a PP-adjunct is typically unstressed; compare (9a) with (9b). Intonation is the sole disambiguator here, a clue that is missing in the written language.

(9) a. du måste ta 'av plåstret. (VPC) you must take off bandaid-the 'You must take off the Band-Aid.'

b. du måste 'ta av 'plåstret. (DP-PP, no VPC) 'You must take some of the Band-Aid.'

2.3.2. German VPCs. In contrast to Swedish, German only allows the order DP-Prt, as shown in (10) for nonfinite and finite verbs. 
(10) a. $\{$ das Diagramm/das $\}$ weg-nehmen \{the chart/it $\quad$ away-take 'to take $\{$ the chart/it $\}$ off'

$\mathrm{a}^{\prime} .{ }^{*}$ weg $\{$ das Diagramm/das $\}$ nehmen (nonfinite VPC)

b. jetzt werde ich $\{$ das Diagramm/das $\}$ weg-nehmen. now will I $\{$ the chart/it $\}$ away-take 'I'll take $\{$ the chart/it $\}$ off now.'

$\mathrm{b}^{\prime} .{ }^{*}$ jetzt werde ich weg $\{$ das Diagramm/das $\}$ nehmen. (finite clause, nonfinite VPC)

c. jetzt habe ich \{das Diagramm/das \}eg-ge-nommen. now have I \{the chart/it away-ge-taken 'I've taken $\{$ the chart/it $\}$ off now.'

$\mathrm{c}^{\prime} .{ }^{*}$ jetzt habe ich weg \{das Diagramm/das genommen. (finite clause, nonfinite VPC)

d. ... wenn ich $\{$ das Diagramm/das $\}$ weg-nehme if I $\{$ the chart/it $\}$ away-take '... if I take $\{$ the chart/it $\}$ off ...'

$\mathrm{d}^{\prime}$. *... wenn ich weg $\{$ das Diagramm/das $\}$ nehme (subordinate clause, finite VPC)

e. jetzt nehme ich $\{$ das Diagramm/das $\}$ weg. now take I $\quad$ the chart/it $\}$ away 'I'll take \{the chart/it\} off now.'

$\mathrm{e}^{\prime} .{ }^{*}$ jetzt nehme ich weg $\{$ das Diagramm/das $\}$. (main clause, finite VPC)

In German, the particle is a separable prefix to the verb, that is, the particle and the verb are compounded whenever there is no verb movement, that is, in all nonfinite contexts (infinitives (10a,b), participles (10c) (ge- being the prefixal part of the past participial circumflex), nominalizations) and in verb-final subordinate clauses (10d). ${ }^{7}$ German is therefore generally assumed to have DPPrt-verb as the underlying order. When overt verb movement applies, particle

\footnotetext{
${ }^{7}$ Particle-verb compounds are found in Swedish too, but only in a few restricted contexts: (i) as adjectival participles (bort-tagen away-taken), (ii) as past participles in the bli-passive construction (bilen hade blivit bort-forslad car-the had been away-moved 'the car had been moved away'), and, optionally, (iii) in synthetic passives (bort-ta-s away-take-PASS 'be taken off/away'), though here the noncompounded VPC is more common (ta-s bort take-PASS away 'be taken off/away'). For past participles in other contexts, noncompounded VPCs are the only option (cf. e.g., jag har tagit bort det I have taken away it).
} 
and verb are separated: The German verb appears in V2 position (as in Swedish), but the particle is stranded at the very end of the clause (unlike in Swedish), resulting in DP-Prt order (10e).

(11) a. German [vP DP Prt V ]

b. Swedish [vp V Prt DP ]

2.3.3. The syntax of VPCs. There is much disagreement regarding the syntactic structure(s) of verb particle constructions. Because many linguists subscribe to the view that syntactic trees are exclusively binary branching, they want the particle to form a constituent with either the verb or the DP (for a dissenting view, see Jackendoff (2002), and, of course, older work (Emonds (1972))).

Today, two major sets of approaches can be distinguished-a complex predicate approach and a small clause approach. The former treats the verb and particle as one complex predicate and the nominal as its complement. Traditionally (e.g., Chomsky (1957), Koster (1975, 171-172)) and in standard textbooks such as Radford (1988b, 90-101), the verb and particle are treated as a complex head, to be listed in the lexicon either as a single word with two heads (12) or as a phrasal unit (e.g., Booij (1990)). The complex verb takes the DP as its direct object. Alternatively, the complex verb is created by some syntactic word formation mechanism, which typically incorporates the particle-overtly or covertly —into the verb (e.g., van Riemsdijk (1978)).

$$
\begin{array}{r}
\text { (12) a. German } \left.\left[\mathrm{vP}^{\left[\mathrm{v}^{\prime}\right.} \underset{\text { das Diagramm }}{\mathrm{DP}} \quad\left[\begin{array}{cc}
\mathrm{v} & \mathrm{Prt}+\mathrm{V}
\end{array}\right]\right]\right] \\
\text { weg-nehmen }
\end{array}
$$

$$
\begin{array}{r}
\text { b. Swedish }\left[\mathrm{vP}_{\mathrm{v}}\left[\mathrm{v}^{\prime}[\mathrm{v} \mathrm{V}+\mathrm{Prt}] \quad \mathrm{DP}\right]\right] \\
\text { ta bort diagrammet }
\end{array}
$$

As has been extensively discussed in the literature, such an approach predicts that when the verb moves to second position, the particle should be carried along, contrary to fact. This problem does not arise if VPCs are analyzed as complex $\mathrm{V}^{\prime}$ structures as in (13), where the particle is generated as a sister to the verb (e.g., Lüdeling (1999, 25, 138), Wurmbrand (1998, 269-270; 2000) for German). Here the verb and particle can be separated by syntactic processes, such as head movement, that is, by the verb raising out of the VP, leaving the particle behind. The particle may or may not head its own projection, $\operatorname{Prt}(\mathrm{P})$.

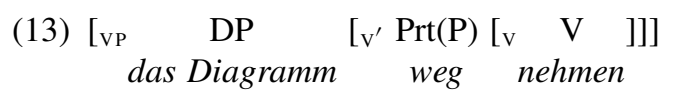

Proponents of the second major type of approach to VPCs do not treat the verb and the particle as one unit but rather the particle and the DP. The verb takes 
a complement in which the nominal and particle form a predicational structure of some sort, or so it is claimed (e.g., Kayne $(1985,101))$, cf. $(14) .{ }^{8,9}$

(14) a. [vp [ das Diagramm weg] nehmen]

b. [vp ta [ bort diagrammet]]

Syntacticians disagree about the underlying order of this predicational constituent: Is it universally DP-Prt (14a), or Prt-DP (14b), or is there parametric variation between languages? It also is an unresolved issue what sort of constituent the nominal and particle actually might form-is it a phrase headed by the particle, PrtP (e.g., Platzack (1998, 177-178), Haegeman and Guéron (1999, 252-267), Zeller $(2001,54)$ ), or a Small clause (SC) (e.g., Kayne (1985), Taraldsen (1983))? The particle would then be the head of the SC (e.g., Hoekstra $(1988,114)$, Grewendorf $(1990,101-103))$ or its projection PrtP would be a subconstituent of a functionally expanded SC (e.g., den Dikken (1995), Svenonius (1996); cf. also Wurmbrand (2000) for semantically transparent VPCs). The different linear orders of German and Swedish VPCs would then be due to a difference in "headedness" of the PrtP/SC, (14a) versus (14b). Or, if there were one universal base order for this constituent, movement of the nominal around the particle or of the particle around the nominal would have to be assumed. Some formal accounts move the DP to a specifier/subject position in the PrtP or SC (e.g., den Dikken (1995), Platzack (1998, 179), Svenonius (1996, 65-67)), others base-generate it there (Hoekstra (1988), Sawyer (2001, 136-137), Wurmbrand $(2000,10))$. Yet others make use of "particle shift" and move the particle into some functional head in the SC (above Prt but below V), for example, Svenonius (1996), as sketched below. ${ }^{10}$

(15) a. $[\mathrm{vp} \ldots[\mathrm{sc} \ldots[\mathrm{prtp} \ldots[$ [DP das Diagramm] [prt weg] $]][\mathrm{v}$ nehmen $]]$

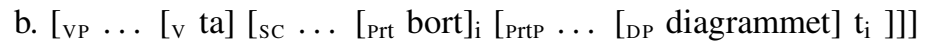
(particle shift)

Here I do not enter further into the current, extensive debate on what the particular structural analysis/analyses of VPCs should be-for lucid overviews

\footnotetext{
${ }^{8}$ The notion that the nominal and the particle form a constituent is supported by the fact that they sometimes can be topicalized together (e.g., Grewendorf (1990)), that the particle semantically often appears to be predicated of the nominal, and that historically the particle in German VPCs sometimes assigned morphological case to the nominal (Grewendorf (1990, 103, 108), Paul (1919/1959, 255, $261)$ ). Often, however, joint topicalization is not possible at all, and predication is implausible. For discussion, see, for example, Grewendorf (1990) and Jackendoff (2002).

${ }^{9}$ The particle is sometimes assumed to incorporate into the verb to form a complex head, a semantically cohesive unit (e.g., Grewendorf (1990), Haegeman and Guéron (1999, 258-267)).

${ }^{10}$ Similarly, VPC word order variation within one language (as in English take away the chart and take the chart away) is derived by movement operations, depending on which order is taken to be the neutral and underlying one.
} 
and more references, see, for example, Wurmbrand (2000), Haiden (2001), and Jackendoff (2002). For the time being, I concentrate on the different linear orders of VPCs in Swedish and German and in the learner data. Finally, in section 5.5, I return to a discussion of the complex predicate and small-clause analyses of VPCs in light of the acquisitional findings presented.

\section{ACQUISITION BACKGROUND}

The present study investigates the acquisition of the three aforementioned areas of clausal syntax: V2 and VP headedness in the L2 German of native speakers of Swedish and in the L2 Swedish of native speakers of German, as well as VPCs in the L2 Swedish of native speakers of German. ${ }^{11}$ German and Swedish are an unusual language combination in acquisition research, with few empirical studies. They are mutually unintelligible, but typologically and syntactically close (e.g., both are V2 languages as we have seen), and lexically very close, with an estimated $80 \%$ of the Swedish lexical entries cognate with German due to common ancestry and a wealth of Low German loans (content words and derivational morphemes).

Recently, the two languages have come into prominence in current L2 acquisition theory, largely due to the claim that native speakers of a V2 language (German, Swedish) violate the V2 constraint when learning another V2 language (Swedish, German). This has been championed by researchers of diverse theoretical persuasions: Platzack $(1996,380 ; 2001)$ working in a generative, Minimalist model, and Håkansson, Pienemann, and Sayehli (2002) working within Processability theory (Pienemann (1998)).

Håkansson et al. (2002) carried out a cross-sectional oral elicitation task with teenage Swedish-L1 learners of German as a foreign language. The German main clauses these learners produced were mostly subject-initial (92\% SVX for learners with 8 months of exposure to German, $85 \%$ for learners with 17 months of exposure) and some were nontargetlike V3 (8\% and 12\% Adv-SVX, respectively), but hardly any were non-subject-initial V2 (0\% and 3\%). Håkansson et al. (256-258) interpreted these results as evidence for "canonical" SVX word order being the initial stage of L2 German and as evidence for a non-V2 interlanguage grammar. They argued that their informants initially violate the V2 constraint because they do not transfer the V2 property from their L1 but undergo a universal sequence of L2 developmental stages (Pienemann (1998)), essentially the same implicational sequence as proposed for Romance-L1 learners [cf. 1.312] of German in the 1980s, for example, by Clahsen, Meisel, and Pienemann (1983) and Clahsen and Muysken (1986). However, as Bohnacker

\footnotetext{
${ }^{11}$ As is common, second language (L2) is understood in a wide sense here where "second" refers to any language added after infancy; a learner may thus acquire one or more L2s.
} 
(2004; 2005) argued in detail, Håkansson et al. draw such conclusions from a rather small database (e.g., only 12 potential contexts for non-subject-initial V2 in the aggregated data from 10 learners). Moreover, the informants' V3 utterances may well be due to influence from English (a non-V2 language), which they had been learning for 4 to 6 years prior to their German being tested. Håkansson et al.'s findings were not verified when Bohnacker (2005; 2006b), using a larger database, studied the acquisition of V2 in Swedish-L1 ab initio learners of German. Her adult informants produced a substantial percentage of non-subject-initial V2 main clauses, and those who had not learned English prior to German never violated the V2 constraint in German (see section 4).

Platzack (2001), also discussing the L2 acquisition of Swedish and German, maintained a related but somewhat different view from Håkansson et al. (2002):

It seems evident from the available literature on Swedish L2 that adults learning Swedish, irrespectively of their L1, usually do not have problems with syntactic phenomena related to the I-domain. The picture is different for $\mathrm{C}$-domain phenomena like V2 and obligatory subject, which are almost never produced fully targetlike (see, e.g. Hammarberg \& Viberg, 1977); Håkansson 1997; Pienemann \& Håkansson, 1999)....

For adult learners of German as a second language, there are indications that Cdomain phenomena like verb second, obligatory subjects, and target-like embedded clauses are less appropriately produced than syntactic phenomena belonging to the I-domain (e.g. Clahsen et al. 1983; Pienemann 1998)....

Summarising the German investigation, the majority of the speakers ... seem to have problems producing C-domain-related syntax, whereas their production of the syntax related to the I-domain is target-like. In general, the German picture is similar to the Swedish one. (371-373)

Unlike Håkansson, Pienemann, and Sayehli (2002), Platzack (2001) did not explicitly rule out the possibility of targetlike non-subject-initial V2 in the early stages of L2 German and L2 Swedish, but he did claim that V2 and other syntactic processes involving the $\mathrm{CP}$ level or C-domain are the hardest to acquire. He hypothesized the left periphery of the clause to be "vulnerable" for all learners. The left periphery is seen as mediating between the propositional content of the clause and the linguistic discourse or discourse situation on the outside. Although this C-domain has traditionally been modeled as one projection level (e.g., Grewendorf (1988, chap. 11)), many current generative models represent it as an extended hierarchy of functional projections, where syntactic and information-structural and other discourse features are matched-for example, Force (illocutionary type, sentence type), Topic, Focus, Fin (finiteness, overt subjecthood) - though there is much disagreement on the exact nature of these projections. Whether there are one or several projections, the C-domain is claimed to be particularly vulnerable because the learners must interface or exchange information between syntax and other cognitive systems, notably 
discourse-pragmatics (e.g., Bhatt and Hancin-Bhatt (2002, 366), Hulk and Müller (2000, 228), Müller and Hulk (2001, 17-19), Platzack (1996; 2001)). Here, it appears to have become widespread to reanalyze what once were considered prime examples of the acquisition of syntax (V2, overt subjects, etc.) as acquisition of the syntax-pragmatics interface, ill-defined as this may be.

Even though Platzack (2001) did not provide any supporting empirical evidence himself, his idea of a vulnerable, or unstable, C-domain and of invulnerable lower clausal domains (IP, VP) has become widespread in certain linguistic circles and has resulted in a number of articles and books (e.g., Müller (2003)).

Note that what Platzack meant by "syntactic phenomena related to the Idomain" in the earlier quote are verb particle constructions and nonfinite verb and object placement (VO/OV). He explicitly located these in the I-domain (2001, 368, 372), but as he himself acknowledged (1998, 132-140), the reasons for doing so are purely theory internal. Platzack's minimalist model (inspired by Chomsky (1993) and Kayne (1994)) rests on a universal SVO base order, where OV and VPC orders are derived by moving elements leftward out of the VP into various functional projections in the I-domain (AktP, AgrOP, etc.). However, a more recent development in syntactic theory eliminates these projections and locates the very same phenomena in the V-domain (by movement into multiple specifier positions, cf. Chomsky (1995)). In acquisition research, one is generally better off not to rely on short-lived formal mechanisms (cf. Schwartz and Sprouse (2000, 158, 183)), and I believe that it is fair to rephrase Platzack as follows: Adult learners of Swedish and German have problems in the C-domain, but their syntax concerning lower clausal domains is targetlike. In fact, Platzack (2003) himself stated that "Platzack 2001 argued that VP syntax is acquired earlier than CP-syntax" (p. 148).

Platzack thus predicted that native speakers of a $\mathrm{V} 2$ language learning another V2 language will (i) initially violate the V2 constraint in the L2 (though it remains unclear whether this will happen all or only most of the time) and (ii) reset VP-related parameters to the target values before they start adhering to the V2 constraint. Specifically then, L1-Swedish learners of German should produce targetlike nonfinite OV before they adhere to the V2 constraint in main clauses. Likewise, L1-German learners of Swedish should produce targetlike nonfinite VO and target V-Prt-DP order in transitive particle constructions before they start adhering to the V2 constraint.

Related to Platzack's idea of (in)vulnerable domains is Bhatt and HancinBhatt's (2002) proposal of Structural Minimality. They also assumed the Cdomain to be vulnerable, but for them this means that the $\mathrm{CP}$ is absent from early L2 grammars and that clausal projections are maximally IPs. Bhatt and Hancin-Bhatt were mainly concerned with native Hindi speakers and their L2 acquisition of the English CP, but they argued that irrespective of the L1/L2 combination, learners at the initial state show no knowledge of $\mathrm{CP}$ and are unable to produce or parse $\mathrm{CP}$ syntax (e.g., subordinate clause structure, question 
formation, adverbials at clause boundaries). Syntactic processes involving the Cdomain, such as movement of the finite verb to $\mathrm{C}$ and movement of phrases to SpecC (as in English questions or non-subject-initial V2 in German and Swedish) should not be found in the productions of elementary learners. Concerning the acquisition of V2 by learners whose L1 also has V2, Bhatt and Hancin-Bhatt thus made the same predictions as Platzack (2001), namely, that VP and IP syntax will be acquired earlier than CP syntax and that V2 will be acquired late.

Vainikka and Young-Scholten (1994; 1996a; 1996b) also maintained that CP is absent in the early stages of L2 grammar but took a more radical stance than Platzack (2001) and Bhatt and Hancin-Bhatt (2002). Based on cross-sectional data from L1 Turkish, Korean, and Romance learners of German, Vainikka and Young-Scholten claimed that no functional projections whatsoever are transferred from the L1 and that all syntactic processes and morphemes associated with the IP- and CP-domains are initially unavailable (Minimal Trees). L1 transfer is restricted to lower, lexical projections (e.g., VP), and changes in VP syntax (such as a switch in VP-headedness to the target L2 value) must precede the acquisition of functional projections (1996b, 20, 25). Vainikka and Young-Scholten's model therefore predicts that native speakers of a V2 language (Swedish, German) learning another V2 language (German, Swedish) will at first be unable to parse and produce $\mathrm{CP}$ syntax, and thus be unable to produce non-subject-initial V2 main clauses. And just like Platzack (2001) and Bhatt and Hancin-Bhatt, they also predict that L2ers will have mastered nonfinite verb-object placement and particle verb constructions before adhering to the V2 constraint.

By contrast, theories of $\mathrm{L} 2$ acquisition that propose a strong native language influence (e.g., Schwartz and Sprouse (1994; 1996), White (1985)), make some very different predictions. According to Schwartz and Sprouse's (1994; 1996) Full Transfer/Full Access model, learners initially produce and process L2 utterances entirely through the L1 grammar and only later change their interlanguage syntax by acquiring new rules and parameter settings. Schwartz and Sprouse thus predict divergent L2 developmental routes with respect to the same target language for groups of learners with typologically distinct L1s. V2 and other operations related to the topmost clause-structural domain (CP) are not universally the most difficult area of syntax to attain, and operations related to lower structural domains are not universally the easiest. In cases where the L1 and the L2 exhibit typological differences in the VP-domain (such as nonfinite verb-object placement and transitive particle verb constructions in Swedish and German), Schwartz and Sprouse $(1994 ; 1996)$ predict transfer of the L1 parameter settings in the domain of VP at the initial state, resulting in delayed acquisition. And in cases where the L1 and L2 are typologically isomorphic (such as V2 in both Swedish and German), they predict transfer of the V2 property in the domain of $\mathrm{CP}$, resulting in virtually immediate acquisition of $\mathrm{V} 2$ in both directions (Swedish-German, German-Swedish). 
The following sections test these predictions on the basis of quantified corpus data from learners of German and Swedish at different proficiency levels.

\section{THE L2 GERMAN STUDY}

Bohnacker (2005; 2006a; 2006b) investigated the acquisition of V2 and OV/VO word order by 23 adolescent and 6 adult (Swedish L1) learners of German. The adolescents were 16-year-old pupils tested once, after 3 years of German classes at a Swedish state secondary school. The adults (old age pensioners) were ab initio learners who were tested after 4 months and 9 months of German classes. Naturalistic production data were collected from all informants with the same elicitation method (recording a spontaneous oral monologue in German in the language lab on a given topic). By comparing ab initio learners for whom German was their first foreign language (L2) with informants who had learned English before taking up German (L3), Bohnacker was able to document two distinct acquisitional paths, with a strong influence of the L2 on L3 syntax, resulting in violations of V2 only in the group that knew English but perfect V2 100\% in the group that did not know English. Here, I only report the results for the ab initio learners for whom German was the first foreign language (see Bohnacker (2006b) for details). As shown in Table 1, they produced both subject-initial and non-subject-initial main clauses, including sizable percentages of non-subject-initial V2 but no nontarget V3 orders (0\% at 4 and 9 months).

But although these learners were mastering V2, other aspects of their interlanguage syntax were strikingly nontargetlike, such as the placement of the non-

TABLE 1

Ab Initio L2 German: Word Order in Main Clauses, Percentages

\begin{tabular}{lcccc}
\hline & $S V X$ & $V 1$ & Non-Subject-Initial V2 & Nontarget V3 \\
\hline 4 months German & & & & \\
Märta & $62 \%$ & $9 \%$ & $29 \%$ & $0 \%$ \\
& $157 / 253$ & $22 / 253$ & $74 / 253$ & $0 / 253$ \\
Algot & $69 \%$ & $0 \%$ & $31 \%$ & $0 \%$ \\
& $43 / 62$ & $0 / 62$ & $19 / 62$ & $0 / 62$ \\
9 months German & & & & \\
Märta & $68 \%$ & $0 \%$ & $32 \%$ & $0 \%$ \\
& $125 / 184$ & $0 / 184$ & $59 / 184$ & $0 / 184$ \\
Algot & $81 \%$ & $0 \%$ & $19 \%$ & $0 \%$ \\
Signe & $104 / 128$ & $0 / 128$ & $24 / 128$ & $1 / 128$ \\
& $62 \%$ & $1 \%$ & $37 \%$ & $0 \%$ \\
& $128 / 206$ & $2 / 206$ & $76 / 206$ & $0 / 206$ \\
\hline
\end{tabular}


TABLE 2

Ab Initio L2 German: Nonfinite Verb Placement in Infinitival Clauses, Sentence Fragments, and Main Clauses with a Complex Verb

\begin{tabular}{lcc}
\hline & Nontarget $V_{\text {nonfin }} X$ & $X V_{\text {nonfin }}$ \\
\hline 4 months German & & \\
Märta & $88 \%$ & $12 \%$ \\
& $89 / 101$ & $12 / 101$ \\
Algot & $70 \%$ & $30 \%$ \\
& $16 / 23$ & $7 / 23$ \\
9 months German & & \\
Märta & $30 \%$ & $70 \%$ \\
& $11 / 37$ & $26 / 37$ \\
Algot & $15 \%$ & $85 \%$ \\
& $4 / 26$ & $22 / 26$ \\
Signe & $38 \%$ & $62 \%$ \\
& $15 / 40$ & $25 / 40$ \\
\hline
\end{tabular}

finite verb vis-à-vis its complement/object. As shown in Table 2, after 4 months of exposure to German, the overwhelming majority of nonfinite verbs precede other material (nontargetlike $\mathrm{V}_{\text {nonfin }} \mathrm{X}$ ).

The average percentage of nontargetlike $\mathrm{V}_{\text {nonfin }} \mathrm{X}(85 \%, 105 / 124)$ drops to $29 \%(30 / 103)$ after 9 months of German. A plausible interpretation for this difference is that at 4 months, the learners have a head-initial VP in their interlanguage grammars (which they could have transferred from L1 Swedish), but in the 9-months recordings, they are beginning to change to a head-final VP. A minimal-pair example is given in (16) and (17).

(16) nun haben ich spielt Boule vier Jahr. now have I played boules four year 'I've now been playing boules for four years.' (Target: nun habe ich vier Jahre Boule gespielt.) (VO, Märta, 4 months)

(17) und dann solln ich Boule spielen. and then shall I boules play 'And then I'll play boules.'

(OV, Märta, 9 months)

This change from a $\mathrm{VO}$ to an $\mathrm{OV}$ interlanguage grammar is not complete at 9 months. It is also entirely unrelated to the mastery of V2: At 4 months, Märta and Algot produce $85 \%$ nontargetlike $\mathrm{V}_{\text {nonfin }} \mathrm{X}$ (Table 2), at a time when their 
ON THE "VULNERABILITY" OF SYNTACTIC DOMAINS

TABLE 3

Oral L2 German: Word Order in Main Clauses.

\begin{tabular}{|c|c|c|c|c|c|}
\hline $\begin{array}{l}3 \text { years } \\
\text { German }\end{array}$ & $S V X$ & $\begin{array}{c}V 1 \\
(V S X)\end{array}$ & $\begin{array}{c}\text { Non-Subject- } \\
\text { Initial V2 } \\
(X V S)\end{array}$ & $\begin{array}{c}\text { Inverted } \\
V 3 \\
(X X V S)\end{array}$ & $\begin{array}{c}\text { Nontarget } \\
\text { V3/V4 } \\
(X S V, X S X V)\end{array}$ \\
\hline 23 informants & $\begin{array}{c}62 \% \\
(754 / 1220)\end{array}$ & $\begin{array}{c}1.5 \% \\
(18 / 1220)\end{array}$ & $\begin{array}{c}32 \% \\
(386 / 1220)\end{array}$ & $\begin{array}{c}2.5 \% \\
(31 / 1220)\end{array}$ & $\begin{array}{c}2 \% \\
(26 / 1220)\end{array}$ \\
\hline
\end{tabular}

Note. Plus $0.4 \%(5 / 1220)$ wh-questions.

non-subject-initial main clauses show perfect V2 $\left(100 \%, 93 / 93\right.$, Table 1). ${ }^{12}$ At this early point in language development then, it is the syntax at a lower clausestructural level that is nontargetlike, rather than grammatical operations at the topmost clause-structural level (CP).

Bohnacker's (2005) results for the 23 adolescent native speakers of Swedish learning German corroborate her findings for the ab initio learners. At 3 years, the 16-year-olds produce sizeable percentages of targetlike non-subject-initial V2 $(32 \%)$ but hardly ever violate V2 (2\% nontarget V3 and V4 in their oral productions), as shown in Table $3 .{ }^{13}$

By contrast, the 16-year-olds' nonfinite verb placement vis-à-vis their complement/object (VP headedness) at 3 years is a lot less targetlike than their finite verb placement (see Table 4). Even though the majority of their nonfinite verbs occur in final position and suggest an interlanguage grammar with a head-final VP, 26\% show nontargetlike $\mathrm{V}_{\text {nonfin }} \mathrm{X}$ placement, a similar percentage to that of the ab initio learners at 9 months. A breakdown of the informants into subgroups reveals that 7 of the 23 learners in fact place $48 \%$ of their nonfinite verbs in the $\mathrm{V}_{\text {nonfin }} \mathrm{X}$ pattern instead of the $\mathrm{XV}_{\text {nonfin }}$ pattern. There is no implicational relation such as "if target V2, then target OV"-most learners who produce nontarget $\mathrm{V}_{\text {nonfin }} \mathrm{X}$ nevertheless have perfect V2. (For further details, see Bohnacker (2006a; 2006b).)

For these learners of German then, the acquisition of V2 is not developmentally dependent on target headedness of the VP (here, OV) having been acquired first: Mastering V2 is much "easier" than mastering VP headedness. This is an odd and problematic finding for acquisition models that assume a universal path of L2 development (e.g., Håkansson et al. (2002)) or a C-domain that is

\footnotetext{
${ }^{12}$ Bohnacker (2005; 2006b) also found that those learners who knew English produced $90 \%$ nontargetlike $\mathrm{V}_{\text {nonfin }} \mathrm{X}$ at 4 months, at a time when, by contrast, around $50 \%$ of their nonsubject initial main clauses were targetlike V2. Thus, learners both with and without knowledge of English produce V2 in German much earlier than head-final VPs.

${ }^{13}$ Inverted V3 (XXVS) are instances of subject-verb inversion (i.e., leftward verb movement past the subject to the C-domain), where two nonargumental elements precede the verb (cf. the discussion around (2) and (3) in section 2.1). For details, see Bohnacker (2005, 45-51).
} 
TABLE 4

Oral L2 German: Nonfinite Verb Placement in Infinitival Clauses, Sentence Fragments, and Main Clauses with a Complex Verb

\begin{tabular}{lcc}
\hline & $V_{\text {nonfin }} X$ & $X V_{\text {nonfin }}$ \\
\hline 3 years German & & \\
23 informants & $26 \%$ & $74 \%$ \\
& $(100 / 389)$ & $(289 / 389)$ \\
Which break down into & & \\
5 informants & - & $100 \%$ \\
& & $(46 / 46)$ \\
11 informants & $16 \%$ & $84 \%$ \\
7 informants & $(31 / 198)$ & $(167 / 198)$ \\
& $48 \%$ & $52 \%$ \\
& $(69 / 145)$ & $(76 / 145)$ \\
\hline
\end{tabular}

vulnerable and an invulnerable V-domain (e.g., Bhatt and Hancin-Bhatt (2002), Platzack (2001)), and for models that invoke L1 transfer at lower, lexical projections only (e.g., VP) but not at higher, functional ones (e.g., CP) (e.g., Eubank (1993/94), Vainikka and Young-Scholten (1994; 1996a; 1996b). Vainikka and Young-Scholten, for instance, explicitly took the switching of VP headedness to the target value to precede the acquisition of any functional projection (1996b, 20, 25). My findings (Bohnacker (2005; 2006b)) are, however, unsurprising on an approach to nonnative language acquisition that invokes full transfer of L1 syntax (e.g., Schwartz and Sprouse (1994; 1996)): Swedish has V2 and its VP is head-initial, whereas German has V2 but its VP is head-final. Transfering the Swedish L1 grammar to German will make finite verb placement in main clauses (V2) easy for the learner but at the same time cause nontargetlike placement of nonfinite verbs - until the parameter setting for VP is changed to head-final.

\section{THE L2 SWEDISH STUDY}

\subsection{Informants, Data Collection, and Method}

Eight adult native speakers of German were studied. They had all had a monolingual childhood in Germany or Austria. At school they had had 7 to 9 years of English as a foreign language (from age 10 or 11); three had also had some years of Latin, two French, and two Latin and French. Regarding Swedish, they were all adult learners; none had been exposed to Swedish before the age of 20. At the time of the study, the informants were long-term residents of Sweden $(3,6,9,15$ years) and they used Swedish every day, in the workplace and/or at 
ON THE "VULNERABILITY" OF SYNTACTIC DOMAINS

TABLE 5

The German Learners of Swedish

\begin{tabular}{lcccc}
\hline In Sweden & 3 Years & 6 Years & 9 Years & 15 Years \\
\hline Stefanie & $\sqrt{ }$ & & & \\
Stella & $\sqrt{ }$ & $\sqrt{ }$ & & \\
Nicole & $\sqrt{ }$ & $\sqrt{ }$ & & \\
Ellen & $\sqrt{ }$ & $\sqrt{ }$ & & \\
Ulrike & $\sqrt{ }$ & $\sqrt{ }$ & $\sqrt{ }$ & \\
Steffen & $\sqrt{ }$ & $\sqrt{ }$ & $\sqrt{ }$ & $\sqrt{ }$ \\
Emma & & & & $\sqrt{ }$ \\
Dirk & & & & \\
\hline
\end{tabular}

home. They were university graduates in their early 20 s to late 30 s, employed at schools, universities, and with the local council as teachers, researchers, cleaners, and psychologists. Although all had been exposed to classroom Swedish, most of their acquisition was naturalistic. Three (Stefanie, Nicole, Ulrike) had attended classes in Swedish as a foreign language in Germany (2 hr/week for 1 year) and began to work immediately upon arrival in Sweden without taking further classes. The other learners (Stella, Ellen, Steffen, Emma, Dirk) had no previous knowledge of Swedish before arriving in Sweden. They attended Swedish classes for immigrants (4-10 hr/week) for 1 year, after which acquisition continued untutored. The learners were advanced in the sense that they were communicating fluently and had passed the respective Swedish university-entry language proficiency exams (Rikstestet/TISUS) before data collection started.

The data from most of these informants are longitudinal and were collected at 3-year intervals: From Stefanie data were collected 3 years after arrival in Sweden; from Stella, Nicole, and Ellen after 3 and 6 years; from Ulrike and Steffen after 3, 6, and 9 years; and from Emma and Dirk after 15 years in Sweden, as indicated in Table 5.

A preliminary analysis of some of this learner data can be found in Bohnacker (2003), but since then, the database has been considerably expanded, with new informants added and old ones recorded again after an additional 3 years. All the data are naturalistic production, spoken and written. (I chose to collect spontaneous production data, as no such corpus of German learners of Swedish exists to my knowledge to date.) The oral data comprise a 45-min recording of the informant narrating events of their life in conversation with an experimenter and a 45-min recording of the informants teaching a class at university or leading a seminar/workshop at the workplace in the absence of experimenters. The recordings were transcribed orthographically. Each recording consists of 500 to 950 utterances, or 5,000 to 7,000 words. Additionally, the informants each supplied 5,000 words of unedited written text (informal e-mails). Oral narratives 
TABLE 6

L2 Swedish Production Data

\begin{tabular}{llll}
\hline In Sweden & Oral: Narrative & Oral: Teaching & Written \\
\hline 3 years & Stefanie & - & Stefanie \\
& Stella & - & Stella \\
& Nicole & - & Nicole \\
& Ellen & - & Ellen \\
& Ulrike & Ulrike & Ulrike \\
& Steffen & Steffen & Steffen \\
6 years & Stella & - & Stella \\
& Nicole & - & Nicole \\
& Ellen & - & Ellen \\
& Ulrike & Ulrike & Ulrike \\
& Steffen & Steffen & Steffen \\
9 years & Ulrike & Ulrike & Ulrike \\
& Steffen & Steffen & Steffen \\
15 years & Emma & Emma & Emma \\
& Dirk & Dirk & Dirk \\
\hline
\end{tabular}

and informal written texts were collected from each learner at every data point, and four learners were also recorded teaching; see Table 6 .

I analyzed the 38 interlanguage transcripts syntactically. In addition to my own judgments-myself not being a native Swedish speaker-I also presented extracts of the transcripts to panels of Swedish native speakers who were training or practicing as language teachers. Because the object of investigation was syntax and not morphology, I edited these transcripts by correcting nontarget morphology ${ }^{14}$ as well as orthographical errors in the case of the written material. This was done so that native speakers judging the transcripts would not home in on morphological errors. Panels frequently commented on what they perceived as high-proficiency levels, and their grammaticality judgments largely matched my own. ${ }^{15}$ Three syntactic traits were repeatedly pointed out as nonna-

\footnotetext{
${ }^{14}$ Morphological "errors" were mostly due to (i) nouns being assigned the wrong grammatical gender, as evinced by nonagreeing determiners and/or adjectives (e.g., en diagram 'a chart,' target ett diagram); (ii) definite suffix omissions resulting in singly definite noun phrases instead of double definiteness (e.g., den store diagram 'the large chart' instead of target det stora diagram-met); (iii) nonagreeing attributive adjectives (e.g., en stor-t sak 'a big thing,' instead of target en stor_sak); and (iv) nontarget number/gender agreement between noun phrase and predicative adjective (e.g., det är klar_ 'that is clear/finished' instead of target det är klar-t $t_{\text {neuter }}$; dom är klar _ 'they are done' instead of target dom är klar-a $\left.a_{\text {PLURAL }}\right)$. Occasionally, nouns were inflected according to the wrong declension class, verbs were inflected according to the wrong conjugation class, and some adverbs had a nontargetlike suffix.

${ }^{15}$ The regular occurrence of non-subject-initial declarative main clauses with targetlike finite verb placement attracted their particular attention. A typical comment was: "But subject-verb inversion is flawless; this must be a native speaker, it can't be an immigrant." This response may be due
} 
ON THE "VULNERABILITY" OF SYNTACTIC DOMAINS

TABLE 7

L2 Swedish: Word Order in Main Clauses (Raw Figures)

\begin{tabular}{|c|c|c|c|c|c|c|c|}
\hline In Sweden & L2er & $S V X$ & $V 1$ & $\begin{array}{c}V 2 \\
(X V S)\end{array}$ & $\begin{array}{c}\text { Targetlike } \\
\text { V3 }\end{array}$ & $\begin{array}{c}\text { Nontarget } \\
\text { V3 }\end{array}$ & Total \\
\hline \multirow[t]{6}{*}{3 years } & Stefanie & 269 & 23 & 181 & 3 & 0 & 476 \\
\hline & Stella & 201 & 14 & 320 & 1 & 2 & 538 \\
\hline & Nicole & 272 & 34 & 264 & 5 & 0 & 575 \\
\hline & Ellen & 277 & 35 & 212 & 10 & 0 & 534 \\
\hline & Ulrike & 454 & 70 & 308 & 19 & 0 & 851 \\
\hline & Steffen & 481 & 65 & 320 & 22 & 0 & 888 \\
\hline \multirow[t]{5}{*}{6 years } & Stella & 370 & 12 & 251 & 14 & 0 & 647 \\
\hline & Nicole & 231 & 23 & 257 & 24 & 1 & 536 \\
\hline & Ellen & 190 & 40 & 230 & 35 & 0 & 495 \\
\hline & Ulrike & 344 & 101 & 401 & 39 & 0 & 885 \\
\hline & Steffen & 391 & 79 & 373 & 53 & 0 & 896 \\
\hline \multirow[t]{2}{*}{9 years } & Ulrike & 392 & 133 & 470 & 60 & 0 & 1,055 \\
\hline & Steffen & 409 & 80 & 533 & 81 & 0 & 1,103 \\
\hline \multirow[t]{2}{*}{15 years } & Emma & 395 & 97 & 480 & 38 & 0 & 1,010 \\
\hline & Dirk & 422 & 89 & 407 & 49 & 0 & 967 \\
\hline Total & & 5,098 & 895 & 5,007 & 453 & 3 & 11,456 \\
\hline
\end{tabular}

tivelike: placement of sentential adverbs and focalizing elements in main clauses, placement of sentential adverbs and negation in subordinated clauses, and in particular the placement of the particle with transitive particle verb constructions in main and subordinated clauses. Here, I concentrate on particle verbs, as these were the only ones to occur regularly in all transcripts.

For investigating verb placement and related phenomena, only a subset of the utterances in the transcripts is relevant. One-word utterances and utterances without a verb were excluded. The remaining multiword utterances with a verb comprise simple sentences, complex sentences containing coordinated and/or subordinated clauses, and sentence fragments, and they make up the relevant data for investigating VP headedness (nonfinite verb placement) and verb particle constructions.

For investigating V2, only main clauses with a subject are relevant. Therefore, subjectless (infinitival/participial) sentence fragments were excluded, as were subjectless imperatives, stand-alone subordinate clauses introduced by a complementizer, and stand-alone indirect questions (where the verb is never in second position in German or Swedish). This leaves 11,456 main clauses containing a verb and a subject (Table 7).

to the strange but widespread notion in Sweden that immigrants speak alike and have roughly the same interlanguage grammar, an idea also perpetuated via many Swedish linguistics textbooks and teacher-training materials (e.g., Bolander (1988, 203, 210), Ekerot (1995, 81-84), Hammarberg and Viberg (1977, 135-138), Nauclér (1995, 124), Viberg (1993, 52-53)). 


\subsection{V2 Results}

The 11,456 main clauses with verb and subject were broken down according to the position of the finite verb vis-à-vis the subject constituent $(\mathrm{S})$ and another constituent (X). Nonreferential det subjects (expletives) were counted as S, just like referential ones. When determining finite verb placement in main clauses, I considered only the first verb, that is, the simplex verb or the first verb of a periphrastic verb construction, and classified this first verb as finite. (In virtually all cases, this verb also carried morphological finiteness/tense marking.)

The columns in Table 7 show instances of SVX, V1 (i.e., VSX), non-subjectinitial V2 (i.e., XVS), ${ }^{16}$ and V3. (In theory, the learners could also have produced V4 or V5 main clauses, but as they never did, no such column is included.) V3 main clauses (without subject-verb inversion) are of two types, XSV and SXV. As shown in previous work (e.g., Bohnacker (2005), recall section 2.1, (2)-(4)), V3 main clauses with certain lexical items are grammatical in native Swedish, most notably XSV with clause-initial consequential connective så 'so,' and XSV and SXV with certain "focalizing" adverbs such as bara 'only' and kanske 'maybe.' I therefore classified V3 learner utterances involving such items as targetlike V3. Other V3 utterances were classified as nontargetlike. In the oral data, there are some instances of a constituent (a hanging topic) followed by an intonational break/pause followed by another constituent followed by the verb, for example, $\AA$ det där vattnet, det luktade hemskt. (and this there water, it smelled gross 'And the water there, that smelled gross.,' Nicole, 3 years). Such hanging topics are targetlike, and as they are not part of the prosodic unit of the clause, as indicated by the intonational break, such utterances were not classified as V3. Only constituents after the break were considered. Accordingly, the previous example det luktade hemskt was classified as SVX.

\footnotetext{
${ }^{16}$ The figures for V2 also include a few instances of XXVS, with two nonargumental constituents preceding the finite verb, as in (i).

(i) a. $\left[\begin{array}{lllll}a & \mathrm{i} & \mathrm{a} & \mathrm{me} & \mathrm{de}(\mathrm{t})]\end{array}\right.$ [så] grejade hon de(t). and in and with this so fixed she it 'And $\{$ so/because of this $\}$ she fixed/got it.' (Ulrike, 9 years, oral narrative)

b. [sen] [så] tycker jag att ni ska förankra det hela i kurslitteraturen. then so think I that you shall anchor the whole in course-literature-the 'And (then) I think you should base it all on (your reading of) the set books.' (Ulrike, 9 years, teaching)

Such XXVS cases have been counted as non-subject-initial V2, as they show subject-verb inversion and are perfectly targetlike. The first preverbal element is a left-dislocated adverbial, the second one a resumptive, så (see Bohnacker $(2005,48-50)$ for a description of this construction). XXVS is not found in any of the transcripts of the six learners recorded at 3 years, but only after 6 years (most after 9 and 15 years), which suggests that this feature of Swedish syntax (not found in German) takes time to acquire.
} 
Table 7 gives the raw figures of the main clause word order types for each informant at the individual data points $(3,6,9,15$ years). Here the three modes (oral narrative, oral teaching, written data)—or for some informants, two modes (oral narrative, written data) - are collapsed, as there were no substantial word order differences between them. Some (targetlike) examples are given in (18).

(18) Ulrike, 3 years, teaching

då gör ja(g) så här å skriver det under det här.

then do I so here and write this under this here

'And now I'm gonna go like this and write this below this here.'

(non-subject-initial V2 declarative with frame topic/connective $d a ̊$ )

$[\ldots]$

[A student complains that they are not familiar with a particular procedure.]

nämen hallå, det vet ni ju redan hur man gör.

but hello this know you well already how one does

'Hey come on, you already know how to do this.'

(non-subject-initial V2 declarative with fronted object det)

nej?—okej, ja(g) visar er igen.

not okay I show you again

'No?'-'Okay, I'll show you again (how to do it).'

(subject-initial declarative)

kollar ni nu alla?

check you now all

'Are all of you watching this now?'

(V1 interrogative)

först denna. å så denna.

first this and then this

'First this one. And then this one.'

$[\ldots]$

- gör ja(g) så här å tar den här.

do I so here and take this here

'And now I'm gonna go like this and take this one here.'

(V1 declarative with zero frame topic)

When the raw figures for the different word orders are converted into percentages (out of all main clauses), we can see their frequencies and development 


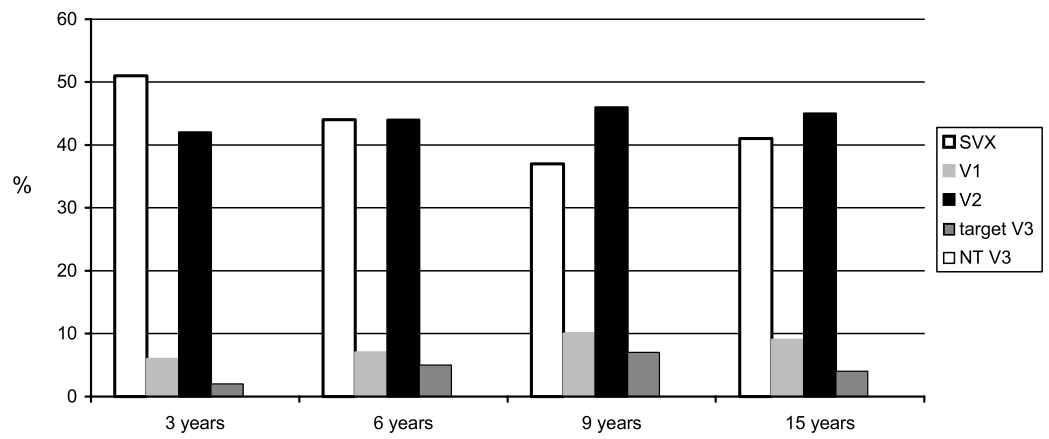

FIGURE 1 L2 Swedish: Word order in main clauses, percentage. Aggregated data.

over time, as visualized in Figure 1. For ease of exposition, the data here have been aggregated for the learners at 3 years, versus 6,9 , and 15 years.

Word order type distribution does not change much during these 3-year intervals. Learners frequently produce both subject-initial SVX as well as non-subject-initial clauses. "Uninverted" SVX, which at 3 years is the most commonbut not the predominant-word order $(51 \%, 1,954 / 3,862)$ becomes slightly less frequent at 6 years $(44 \%, 1,526 / 3,459)$ and is surpassed by non-subject-initial V2 plus V1 ("subject-verb inversion"). V1 wavers between $6 \%$ and $10 \%$, nonsubject-initial V2 between $42 \%$ and $46 \%$. Interestingly, targetlike V3 word order, which is rare at 3 years (2\%), increases in frequency at 6 and 9 years (5\%-7\%). This is largely due to an increase in så-initial clauses in the oral data, which suggests that this Swedish-particular word order (recall section 2.1), which does not exist in German, may take some time to acquire.

Crucially, however, none of the learners has a problem with V2; they place the finite verb in second position (or in first position in V1 clauses) in a completely targetlike manner. This holds for learners at all levels (Table 7). For 36 of the 38 transcripts, nontarget V3 is not attested at all, a fact that panels also frequently commented on when judging extracts, and overall, there is only a vanishingly low $0.026 \%$ of nontarget V3, that is, 3 instances in a corpus of 11,456 main clauses. These data clearly do not bolster proposals of a vulnerable $\mathrm{C}$-domain or of V2 being hard to acquire in L2A. ${ }^{17}$

For these adult learners, then, the Swedish syntax involving the C-domain (V2) does not appear to be a difficult area to attain. This is not to deny that it may be so for other learners; indeed, many studies have shown that L2 learners whose L1 is non-V2 do not or do not fully adhere to the V2 constraint of the L2 they

\footnotetext{
${ }^{17}$ Also, these learners do not omit obligatory subjects. Subject omission has been said to be a feature of L2 Swedish and related to a nontarget or vulnerable C-domain (Platzack $(2001,371)$ ).
} 
are acquiring, despite often years of naturalistic exposure, for example, Bolander (1988, 207-210; 1989) for L2 Swedish learners with L1 Finnish, Polish, or Spanish (unfortunately, she bulks the learners together irrespective of their L1s). L2 German studies of Romance, Turkish, and Korean native speakers show similar results (cf. e.g., Clahsen and Muysken (1986), duPlessis, Solin, Travis, and White (1987), Schwartz and Sprouse (1994; 1996), Vainikka and YoungScholten $(1994 ; 1996 a ; 1996 b))$. My data here come from subjects with a V2 language acquiring another V2 language, and V2 is not a problem. This result may be unsurprising to some readers; indeed it does fit with most traditional and more recent generative full L1 transfer accounts of L2 acquisition. However, it is at variance with approaches that posit universal L2 developmental stages and those current generative models that assume a vulnerable $\mathrm{C}$-domain.

\subsection{VP Headedness: Results}

One might object to the aforementioned conclusion on the grounds that the L2 Swedish data come from perhaps too advanced or exceptional learners who do not have problems with the syntax of the $\mathrm{C}$-domain any more than they have with lower domains (VP, IP). As is shown in the next section (5.4), this objection does not hold, as the learners clearly do produce nontarget structures connected with those lower domains, namely, transitive particle verb constructions.

But before doing so, I briefly summarize the findings for the placement of nonfinite verbs. Nonfinite verbs (infinitives, participles) were culled from finite clauses with complex verbs (Aux $+\mathrm{V}$ ) and from nonfinite constructions (infinitival clauses, root infinitives, sentence fragments) and classified according to their position in relation to other constituents $\left(\mathrm{V}_{\text {nonfin }} \mathrm{X}\right.$ versus $\left.\mathrm{XV}_{\text {nonfin }}\right)$.

The learners exhibit targetlike nonfinite verb placement at all data points, though for reasons of space I only present the results for the least advanced learners (i.e., those who spent 3 years in Sweden) here. As shown in Table 8, their nonfinite verb placement is $99.5 \% \mathrm{~V}_{\text {nonfin }} \mathrm{X}$, which suggests that their VP is head-initial. Because no data were collected from these learners at more elementary levels, we do not know what their VP syntax looked like at the initial state. We do know that at 3 years they have acquired Swedish VO.

\subsection{The Learners' Verb Particle Constructions: Results}

Panel members judging extracts of the L2 Swedish transcripts frequently remarked on the nontargetlikeness of transitive VPCs, and the full transcripts showed that these indeed were a problem. The learners often produce V-DP-Prt structures as in (19a,b,c), instead of the target V-Prt-DP order $\left(19 \mathrm{a}^{\prime}, \mathrm{b}^{\prime}, \mathrm{c}^{\prime}\right)$, and for all learners tested at 3 years, the nontarget order predominates in both finite (19a,b) and nonfinite VPCs (19c). 
TABLE 8

Oral and Written L2 Swedish: Nonfinite Verb Placement in Infinitival Clauses, Sentence Fragments, and Main Clauses with a Complex Verb

\begin{tabular}{lcc}
\hline & Target $V_{\text {nonfin }} X$ & Nontarget $X V_{\text {nonfin }}$ \\
\hline 3 years in Sweden & & \\
$\quad 6$ informants & $99.5 \%$ & $0.05 \%$ \\
& $(1075 / 1080)$ & $(5 / 1080)$ \\
Which break down into & & \\
Stefanie & 158 & 1 \\
Stella & 129 & 0 \\
Nicole & 160 & 1 \\
Ellen & 119 & 0 \\
Ulrike & 213 & 3 \\
Steffen & 296 & 0 \\
\hline
\end{tabular}

(19) a. Ulrike, 3 years, teaching nu stänger vi den av, ja? now switch we it off yes 'Now we'll switch it off, all right?'

$\mathrm{a}^{\prime}$. Swedish target nu stänger vi av den.

b. Ulrike (U), 3 years, oral narrative, telling interviewer (I) about hiking in Lapland

I: å myggen då, var inte dom besvärliga? and mosquitoes-the then were not they a-nuisance 'But the mosquitoes, weren't they quite a nuisance?'

$\mathrm{U}$ : jo, men naturen var så vackert att vi glömde dom bort. yes, but nature-the was so beautiful that we forgot them away 'Well yes, but the landscape was so beautiful that we forgot about them.'

$\mathrm{b}^{\prime}$. Swedish target ... att vi glömde bort dom.

c. Ulrike, 3 years, written narrative about a stray cat that got into her apartment

då fick jag köra katten ut för att få henne ut. then got I drive-INF cat-the out for to get-INF her out 'I had to shoo the cat away in order to get rid of her.'

$\mathrm{c}^{\prime}$. Swedish target då fick jag köra ut katten för att få ut henne. 
ON THE "VULNERABILITY" OF SYNTACTIC DOMAINS

TABLE 9

L2 Swedish: Word Order in Transitive Verb Particle Constructions (Raw Figures)

\begin{tabular}{|c|c|c|c|c|c|}
\hline In Sweden & L2er & $V-(\ldots)-P r t-D P$ & $V-(\ldots)-D P-P r t$ & Total & $\%$ Nontarget \\
\hline \multirow[t]{6}{*}{3 years } & Stefanie & 0 & 17 & 17 & 100 \\
\hline & Stella & 1 & 31 & 32 & 97 \\
\hline & Nicole & 0 & 20 & 20 & 100 \\
\hline & Ellen & 3 & 25 & 28 & 89 \\
\hline & Ulrike & 8 & 34 & 44 & 81 \\
\hline & Steffen & 21 & 28 & 49 & 57 \\
\hline \multirow[t]{5}{*}{6 years } & Stella & 5 & 23 & 28 & 82 \\
\hline & Nicole & 31 & 17 & 48 & 34 \\
\hline & Ellen & 22 & 28 & 50 & 56 \\
\hline & Ulrike & 37 & 24 & 61 & 39 \\
\hline & Steffen & 50 & 15 & 65 & 23 \\
\hline \multirow[t]{2}{*}{9 years } & Ulrike & 51 & 14 & 65 & 22 \\
\hline & Steffen & 44 & 2 & 46 & 4 \\
\hline \multirow[t]{2}{*}{15 years } & Emma & 45 & 3 & 48 & 6 \\
\hline & Dirk & 53 & 4 & 57 & 7 \\
\hline
\end{tabular}

Table 9 provides a quantitative breakdown of the learners' transitive VPCs according to word order. I searched all multiword utterances (main and subordinate clauses, finite and nonfinite clauses and sentence fragments) for VPCs with a nominal. These were classified as V-(...)-Prt-DP or V-(...)-DP-Prt. There also could have been other word orders (e.g., with the verb following DP and particle instead of preceding them), but as the learners did not produce any such VPCs, no such column was included. I use Prt (and not PrtP), as there were no complex/modified particles. V-(...)- indicates that the verb preceding DP and particle may be immediately adjacent or nonadjacent. Table 9 combines the oral and written data of an informant for each data point.

After 3 years in Sweden, five of the six learners exclusively or near exclusively produce nontarget V-(...)-DP-Prt order (100\%-81\%), and the sixth learner often does so (Steffen, 57\%). There is a clear development over time: DP-Prt decreases for all learners recorded more than once-for instance, for Ulrike from $81 \%$ at 3 years to $22 \%$ at 9 years, for Steffen from $57 \%$ at 3 years to $4 \%$ at 9 years, and the learners tested after 15 years only produce few of these nontarget structures (6\%-7\%). This development is sketched in Figure 2.

For these learners of Swedish, the syntax of VPCs remains nontargetlike for 6,9 , or more years, whereas the same learners have $100 \%$ targetlike main clause word order (V2) and $99.5 \%$ targetlike VP headedness (nonfinite verbs) by 3 years.

After an early stage of (near) exclusive DP-Prt for five of the six learners, they enter a stage where two VPC word orders coexist for a long time (optionality). It is difficult to make out any factors that might determine the choice of one VPC 


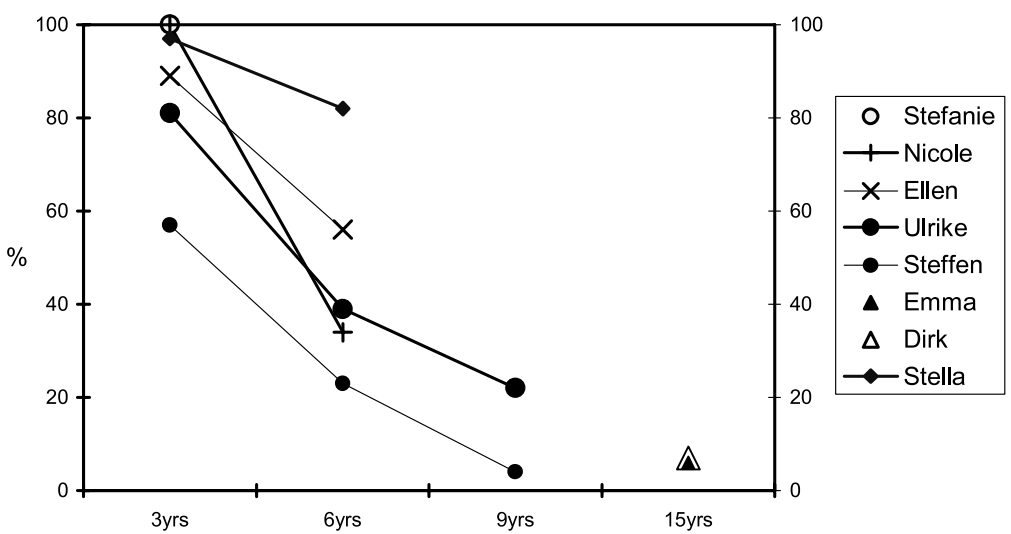

FIGURE 2 L2 Swedish: Percentage of nontarget V-(...)-DP-Prt out of all transitive verb particle constructions.

order over the other. For instance, there does not seem to be any correlation of VPC order either with finiteness or nonfiniteness of the verb or with the verb having moved or not (19).

One might suppose that certain lexical particles correlate with one word order and other particles with the other, but this is clearly not the case, as one and the same particle often occurs with both word orders in the same transcript. Most VPCs contain the particle upp 'up,' ut 'out,' bort 'away/off,' or av 'off,' all of which are high-frequency particles in Swedish. Nevertheless, the learners at 3 years use these particles overwhelmingly with nontarget V-(...)-DP-Prt order and later on with both word orders (cf. (20)).

(20) Ellen, 6 years, oral data

a. kan du ställa kaffekitteln bort, tack? can you put coffee-pot-the away thanks 'Could you take the coffeepot off (the stove), please?'

$\mathrm{a}^{\prime}$. target: kan du \{ställa undan/ta bort kaffekitteln\} tack? can you \{put away /take away coffee-pot-the $\}$ thanks

b. å sen tog ja(g) bort den där lappen igen. and then took I away the there paper-the again 'And then I took that piece of paper off again.' (targetlike)

Prt-DP order might also be learned separately for each specific verb-particle combination in a piecemeal fashion. This is unlikely though, as the learners who were tested more than once used the same verb-particle combination first as DP-Prt, later both as DP-Prt and Prt-DP, and sometimes still later as Prt-DP only. This is most evident for Ulrike and Steffen, who were recorded at 3,6, and 
9 years in similar teaching contexts, which favored the repeated use of certain VPCs, such as skriva upp $X$ 'write down,' ta bort $X$ 'take away/off,' lägga till $X$ 'add,' and lägga på $X$ 'put on.' These constructions show a change from particle-final to particle-initial, suggesting that the learners are restructuring their grammars over the years (cf. (21)-(22)).

(21) a. Steffen, 3 years

jag skriver det upp. (nontarget)

I write it up

'I'll write it down.'

b. Steffen, 6 years

ja(g) ska skriva det upp här då. (nontarget)

I will write it up here then

'I'll write it down here then.'

c. Steffen, 6 years

har ni skrivit upp detta nu?

have you written up that now

'Have you got that written down now?'

d. Steffen, 9 years

jag skriver upp det.

I write up it

'I'll write it down.'

(22) a. Ulrike, 3 years

nu tar jag folien bort. (nontarget)

now take I slide-the away

'Now I'll take the slide away/off.'

b. Ulrike, 3 years

å om vi tar det bort nu ... (nontarget)

and if we take it away now

'And if we're taking it away now ...'

c. Ulrike, 6 years

men nu kan ja(g) väl ta det bort, eller hur? (nontarget)

but now can I well take it away, or how

'But now I can take/wipe it off, can't I?'

d. Ulrike, 6 years

å för att ta bort de(t), så ...

and for to take away it so

'And in order to take it away, ...'

e. Ulrike, 9 years

men om vi nu tar bort diagrammet...

but if we now take away chart-the

'But if we now take away the chart...' 
However, in most cases it is difficult to determine whether a certain verbparticle combination can only occur with a particular word order in the learner's grammar. Due to the nature of the corpus (spontaneous production data), most verb-particle combinations only occur once, or perhaps twice, per transcript. One such minimal-pair example is given in (23). A more experimental study would be necessary to decide this point.

(23) Ulrike, 9 years, oral data, about information to be put on a Web site

a. då kan man ju lägga de(t) ut sen. then can one well lay it out later 'Well, then one can put it on the Web site later.' (nontargetlike)

b. men om man nu lägger ut de(t) i alla fall?

but if one now lays out it in any case

'But if one puts it on the Web site now anyway?' (targetlike)

When investigating the "optionality" of the two VPC word orders, one might expect to find a differentiated distribution depending on the nominal, for example, VPCs with a nonpronominal DP might show a different word order from those with a (phonologically light) pronoun. ${ }^{18}$ However, I have not been able to detect any such pattern for the L2ers in the present study.

There are some clearly idiomatic VPCs (e.g., skämma bort henne shame away her 'give her a treat'; skämma ut sig shame out self 'disgrace oneself'), but most of the learners' VPCs are semantically relatively transparent (e.g., ta bort sniglarna take away slugs-the 'take away the slugs,' hänga upp dom hang up them 'hang them up,' klä av sig clothe off self 'take off one's clothes'), as has also been found for VPCs in child language (Sawyer (2001, 141-151)). I could not detect any tendency for idiomatic or transparent VPCs to occur more often with a particular word order.

The learners seem to be using VPCs productively and even create some novel VPCs, as Ellen's klä mig för (dress me for 'dress up as') in (24). This novel form is morphologically similar to German sich ver-kleiden (self for-dress 'to dress up,'ver- being an inseparable prefix) and Swedish klä ut sig (dress out self 'to dress up as'), but Ellen sticks to DP-Prt word order, ignoring the interviewer, who provides her with the target Prt-DP form:

(24) Ellen (E), oral narrative, 6 years, with interviewer (I)

$\mathrm{E}$ : ja(g) har klätt mig för som tomte.

I have dressed me for as Father-Christmas 'I dressed up as Father Christmas.'

\footnotetext{
${ }^{18}$ This is indeed what Platzack (2003, 146-147) suggests is happening in the L1 acquisition of Swedish VPCs, where the three children he studied occasionally produce nontarget DP-Prt orders (4.4\%) (7/159)), and these mostly involve a light pronoun, for example, *lägga den bort 'put it away.'
} 
I: du klädde $\underline{\text { ut }}$ dig? you dressed out you 'You dressed up?'

E: ja, ja(g) klädde mig ut som tomte med skägg å allt. yes I dressed me out as Father-Christmas with beard and all 'Yeah, I dressed up as Father Christmas with a beard and all.'

target: jag klädde ut mig till tomte.

\subsection{Discussion: Verb Particle Constructions and VP}

Why does it take the learners so long to get to the point where they regularly produce targetlike VPCs when they have no problem with V2?

I suggest that the answer lies in their German L1 grammar and in having transferred this grammar to the L2 (cf. Schwartz and Sprouse (1994)). Both languages are V2 and have finite verb movement. German has a head-final, Swedish a head-initial VP. VPCs have opposite orders of DP and particle in the two languages (25)-irrespective of the syntactic formalism chosen to model this $\left(\mathrm{V}, \mathrm{V}^{\prime}\right.$, PrtP, or SC; recall section 2.3).

(25) nonfinite

a. German [vp [ das Diagramm weg] nehmen]

b. Swedish [vp $t a$ [ bort diagrammet $]]$

finite V2 clause

c. German [ ${ }_{\mathrm{cp}}$ jetzt nehme $_{\mathrm{i}}\left[\right.$ ich [vp [ das Diagramm weg] $\left.\left.\mathrm{t}_{\mathrm{i}}\right]\right]$ ]

d. Swedish [cР $n u \quad \operatorname{tar}_{\mathrm{i}} \quad$ [ jag [vp $\mathrm{t}_{\mathrm{i}}$ [ bort diagrammet]]]]

On a full transfer approach, the L2ers initially use their German L1 grammar to produce and process utterances in the new language and only later may restructure their interlanguage grammar by acquiring new rules, parameter settings, and constraints. Thus, the learners are predicted to produce V2 clauses from the start (which is perfectly targetlike) but also to initially produce nontargetlike VPCs as sketched in (26) and (27).

(26) predicted L1 German L2 Swedish interlanguage nonfinite [vp [ diagrammet bort] ta ]

(27) predicted L1 German L2 Swedish interlanguage finite V2 [ср nu tar [ jag [vp [ diagrammet bort ]]]]

As the learners in the present study were not recorded at the initial state, we do not know what sort of VPCs they were producing then, if any. Further 
empirical studies are needed to determine this. However, we do know that after 3 years the learners produce nontargetlike finite VPCs of the type as in (27), as predicted. We also know that their nonfinite VPCs do not look like (26) (or perhaps not anymore), but rather like (28), particle-final as in German, and verb-initial as in Swedish.

(28) attested interlanguage nonfinite VPC: ta diagrammet bort

These findings are easily reconciled. The predicted and attested nontarget order of finite VPCs in (27) can be derived in two ways-the finite verb, which has moved to second position, may have originated in a head-final VP (as in German) or in a head-initial VP (as in Swedish), we cannot determine this from the surface order in (27) (cf. $\left(27^{\prime} \mathrm{a}, \mathrm{b}\right)$ ).

$\left(27^{\prime}\right)$ a. [ср $n u \operatorname{tar}_{i}[$ jag [vp [ diagrammet bort $\left.\left.\left.] \mathbf{t}_{\mathbf{i}}\right]\right]\right]$

b. [ср nu $\operatorname{tar}_{i}\left[\right.$ jag [vp $\mathbf{t}_{\mathbf{i}}$ [ diagrammet bort $\left.\left.\left.]\right]\right]\right]$

As the learners do not produce verb-final nonfinite VPCs (i.e., not (26) but (28)), their VP here is most likely to be head-initial. From the findings concerning nonfinite verbs and complements (section 5.3) we also know that VP headedness, at least by 3 years (but perhaps much earlier), has been set to the head-initial target value of Swedish. Yet, overwhelmingly, at 3 years, still frequently at 6 years, and occasionally even later, the learners are using their L1 syntax as far as DP-particle is concerned.

On an approach that treats particle and DP as a constituent of some sort, and abstracting away from analytical questions concerning the structural details of that constituent (section 2.3), we could sketch the interlanguage VPC representation as follows: Headedness of the VP has changed from final to initial, whereas "headedness" of the SC or PrtP has not yet changed from particle-final to particle-first, (29)-(31). ${ }^{19}$

(29) Swedish: verb-initial VP, particle-initial SC

$$
\left[\mathrm{vp} \ldots[\mathrm{v} t a]\left[\mathrm{sc} \ldots[\text { [prt bort }]\left[{ }_{\mathrm{DP}} \text { diagrammet }\right]\right]\right]
$$

\footnotetext{
that what the learners do is to not apply "particle shift" (e.g., Svenonius (1996)), which is said to be obligatory in Swedish but not to exist in German.

(i) German: verb-final VP, no particle shift

[vp ... [Sc ... [PrtP ... [DP das Diagramm] [prt weg]]] [v nehmen]]

(ii) Swedish: verb-initial VP, particle shift

$\left[\mathrm{vP} \ldots[\mathrm{v} t a]\left[\mathrm{sc} \ldots[\text { [Prt bort }]_{\mathrm{i}}[\mathrm{PrtP} \ldots\right.\right.$ [DP diagrammet $\left.\left.\left.] \mathrm{t}_{\mathrm{i}}\right]\right]\right]$

(iii) L2 interlanguage: verb-initial VP, no particle shift

[vp ... [v $t a][\mathrm{sc} \ldots[$ [PrtP ... [DP diagrammet $]$ [P bort]]]]
}

${ }^{19}$ Alternatively, if one were to assume an invariant underlying order of the SC, one could say 
(30) Native German: verb-final VP, particle-final SC

[vp ... [sc ... [ [

(30') Hypothesized initial-state L2 grammar transferred from L1 German: verb-final VP, particle-final SC

$\left[\mathrm{vp} \ldots\left[\mathrm{sc} \ldots\left[{ }_{\mathrm{DP}}\right.\right.\right.$ diagrammet $]\left[{ }_{\mathrm{Prt}}\right.$ bort $\left.]\right][\mathrm{v}$ ta $\left.]\right]$

(31) Change in the L2 grammar: verb-initial VP, particle-final SC [vp $\left.\ldots .{ }_{\mathrm{v}} \mathrm{ta}\right]\left[\mathrm{sc} \ldots\right.$ [ ${ }_{\mathrm{DP}}$ diagrammet $][\mathrm{prt}$ bort $\left.]\right]$

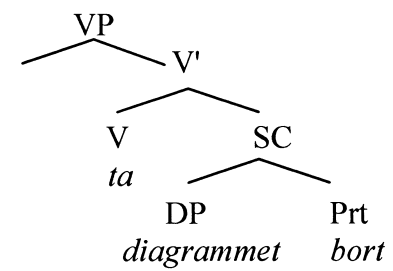

(32) Further change in the L2 grammar: verb-initial VP, particle-initial SC (corresponding to native Swedish)

$\left[\mathrm{vp} \ldots\left[{ }_{\mathrm{v}} t a\right]\left[\mathrm{sc} \ldots{ }_{\mathrm{Prt}}\right.\right.$ bort $][\mathrm{DP}$ diagrammet $\left.\left.]\right]\right]$

Whether the verb in (31) moves out of the VP into a higher projection (in finite VPCs) or not (in nonfinite VPCs) will not alter the particle-final order, and this is the order we find in the nontarget L2 productions. Thus, a SC or PrtP analysis of VPCs captures the learner data because the headedness of the SC/PrtP can be differentiated from the headedness of the VP, allowing for a change at a different, later stage of development.

By contrast, a complex predicate approach to VPCs (section 2.3) does not capture the learner data so well. Consider the structure of VPCs in native Swedish and German according to this analysis (33)-(34).

(33) Swedish: head-initial VP

$\left[\mathrm{vp}_{\mathrm{v}}[\mathrm{v} t a][\mathrm{prt}\right.$ bort $\left.]\right][\mathrm{DP}$ diagrammet $\left.]\right]$

(34) German: head-final VP

[vp [DP das Diagramm] [v' [prt weg] [v nehmen]]]

(34') Hypothesized initial-state L2 grammar transferred from L1 German: head-final VP

[vP $\left[{ }_{\mathrm{DP}}\right.$ diagrammet $]{ }_{\mathrm{v}^{\prime}}\left[{ }_{\mathrm{Prt}}\right.$ bort $][\mathrm{v}$ ta $\left.\left.]\right]\right]$

(35) Hypothesized change in the L2 grammar: head-initial VP

a. $\quad\left[\mathrm{vp}_{\mathrm{v}^{\prime}}[\mathrm{prt}\right.$ bort $][\mathrm{v}$ ta $\left.]\right][\mathrm{DP}$ diagrammet $\left.]\right]$

b. $\mathrm{V}_{\mathrm{i}} \ldots\left[\mathrm{vp}_{\mathrm{vp}}\left[\mathrm{v}^{\prime}[\mathrm{prt}\right.\right.$ bort $\left.]\left[\mathrm{v} t_{i}\right]\right][\mathrm{DP}$ diagrammet $\left.]\right]$ 
At the initial state, learners are predicted to transfer the hypothesized German structure $\left(34^{\prime}\right)$. The findings in section 5.4 indicate that by 3 years, the learners have acquired a Swedish-style head-initial VP. For the acquisition of VPCs, this should have the following consequence: If the particle and the verb form a complex predicate, the DP being its complement, VP headedness will determine the position of the particle with respect to the DP. In main clauses, the V2 property will move the finite part of the verb away, but the linear ordering of particle and complement should remain the same. This means that once the headedness of the VP has changed to being head-initial (35), the verb-particle complex will be located to the left of the DP, which should result in linear PrtDP order, as pointed out by one Language Acquisition reviewer. This, however, is not what the L2ers are doing, since at 3 and 6 years, they largely place the particle to the right of the DP (recall Table 8, Figure 2). The complex predicate VPC analysis predicts that the particle should precede the DP at this stage both when the verb is nonfinite (35a) and when the verb has moved leftward in finite main clauses (35b), contrary to fact. This suggests that the complex predicate analysis is wrong and the SC/PrtP analysis is right.

Alternatively, as noted by a Language Acquisition reviewer, the VPCs in these interlanguage grammars might (a) simply not obey the rules that primary languages apply (i.e., not be constrained by UG) or (b) have a syntactic configuration that cannot be derived from German and Swedish but is attested in other languages. Because all informants have learned English prior to learning Swedish, English particle shift might be a possible answer here, though we would then expect to find the same pronoun versus lexical DP asymmetry that English particle shift exhibits, which is not the case.

On a full transfer approach, development is failure driven such that L2 input that cannot be assigned a representation on the L1 grammar will force restructuring and thus trigger grammar change. However, as many empirical studies have shown, learners do not necessarily (directly) settle on the target grammar but may restructure to a (UG-constrained) grammar that is still not the target one. Indeed, the learners' interlanguage grammar in the present study looks much like older versions of Swedish and like modern Danish today (Herslund (1984, 40-42), Hulthén (1947, 159-165)), ${ }^{20}$ which also exhibit V2, a head-initial VP, and VPCs with DP-Prt order.

Why would it take the German learners of Swedish so long to arrive at the target VPC order, getting stuck on DP-Prt in the VP for at least several years? Here, one should keep in mind that the sheer amount of input regarding the ordering of Prt and DP in VPCs is much, much smaller than for other syntactic phenomena such as verb placement. To give some indication, in a

\footnotetext{
${ }^{20}$ According to Teleman et al. (1999a, 435), modern Finland Swedish also allows optional DPPrt, especially when a PP follows the VPC. Hulthén $(1947,159-163)$ noted optional DP-Prt in older varieties of Finland Swedish and Scanian Swedish.
} 
corpus of naturalistic adult-to-child speech, Swedish-speaking caregivers were found to produce 12,758 non-subject-initial V2 main clauses, 1174 instances of nonfinite verb-object, but only 515 VPCs (CHILDES data from Harry's, Sara's, and Markus' caregivers, counts based on Josefsson (2003, 125-130) and Platzack (2003, 144)).

Also pointing toward an imbalance between nonfinite verb-object and VPCs are the productions of the L2 informants themselves: the files of the six learners at 3 years contain 1,906 non-subject-initial main clauses, 1,080 nonfinite VO/OV, but only 190 instances of transitive VPCs.

In addition to a low overall input frequency, acquisition may be hampered by ambiguous and misleading primary linguistic data (input), which may suggest to the learners, once they have changed VP headedness, that VPCs with a "headfinal" SC/PrtP are acceptable. For instance, recall that Swedish VPCs with a reflexive pronoun often allow $\mathrm{V}-(\ldots)-\mathrm{DP}_{\text {reflexive}}$-Prt order, though how frequent the order reflexive-Prt is in adult-to-adult discourse remains to be determined. ${ }^{21}$ Similarly, VPCs in non-subject-initial main clauses with synthetic passives or unaccusatives (recall fn. 6) exhibit V-(...)-DP-Prt order.

The learners may also be misled into keeping German-style DP-Prt by the frequent occurrence of the linear order DP-"Prt" in non-VPC constructions that involve an element (near-)homophonous with the particle of a VPC. Such DP"Prt" arises when a direct object DP is followed by certain locational and directional one-word adverb(ial)s, as in (36b) and (37b). ${ }^{22}$

(36) a. jag har lämnat in nyckeln. (VPC)

I have left in key-the

'I've handed in the key.'

b. jag har lämnat nyckeln i. (no VPC, but DP-Adv)

I have left key-the in

'I've left the key in (the lock).'

\footnotetext{
${ }^{21}$ In the aforementioned CHILDES corpus, none of the adults' 515 VPCs had that order (Platzack (2003, 139)), but it appears that VPCs with reflexives were not common anyway.

${ }^{22}$ In a related vein, Platzack $(2003,139)$ suggested that learners (in his case, L1 children who produce V-DP-Prt)—instead of true VPCs-might produce a verb plus direct object plus an elliptic locative/directional PP with a P head and an empty complement, as in (ia).

(i) a. child: jag har lagt [DP luren ] [РP ... [Р på] [DP Ø]].$$
\text { I have put receiver-the on } \varnothing
$$

b. target: jag har lagt [sc/Prtp på luren ].

I have put on receiver-the

'I've put the receiver on (the hook) (i.e., I've put the phone back on the hook.)'
}

The adults in the aforementioned CHILDES corpus produced only one instance of DP-Prt amenable to the analysis in (ia), but 514 VPCs with Prt-DP order (Platzack $(2003,147)$ ). 
(37) a. jag ska ta hem bilen. (VPC)

I will take home car-the

'I'll take the car home. i.e., I'll see to it that the car ends up (back) home.'

b. jag ska ta bilen hem. (no VPC, but DP-Adv)

I will take car-the home

'I'll take the car home. i.e., I'll go home by car.'

The linear order of DP-"Prt" also arises when a direct object DP is followed by a complex PP that contains an adverb (homophonous with a VPC-particle) and a PP. This frequently happens with complex locational and directional PPs, as in (38b): DP-[PP Prt-PP]. In such constructions, $\mathrm{P}$ might be the head and the Prt its specifier, or Prt might be the head and the PP its modifier (cf. Jackendoff $(2002,74-76,93))$, with only a subtle difference in meaning.

(38) a. jag ska ta in bilen [PP till stan]. (VPC)

I will take in car-the to town-the

'I'll take the car into town.'

b. jag ska ta [DP bilen ] [PP in [PP till stan ]]. (no VPC, but DP-PP)

I will take car-the in to town-the

'I'll take the car into town. i.e., I will go to town by car.'

Similarly, the string DP-"Prt" also arises when a direct object DP is followed by a PP that contains a preposition homophonous with a VPC-particle and a nominal complement, that is, V-DP-[PP P-DP], as in (39). The direct object is thematically identical with the nominal in a VPC. Here however, the PPpreposition is typically unstressed, unlike VPC-particles, which always carry stress.

$$
\begin{aligned}
& \text { DP-PP jag har lagt }\left[_{D P} \text { den }{ }_{[P P} \ldots{ }_{P} \text { på] }{ }_{D P}\right. \text { bordet } \\
& \text { I have put it on table-the } \\
& \text { / lådan / minnet ]]. } \\
& \text { / mailbox-the / memory-the } \\
& \text { 'I've put it on the table/put it in the mailbox/committed it to } \\
& \text { memory.' }
\end{aligned}
$$

Note that in all of these cases, the string DP-Prt occurs not only in Swedish but also in German, the learners' L1. I have suggested that low input frequency and ambiguous and misleading primary linguistic data may serve as explanations for why the learners get stuck on the DP-Prt order. I leave further investigation of these issues for future research. 


\section{CONCLUSION}

The present study has investigated learner data from L2 German and L2 Swedish. I have tried to show that syntactic operations related to the topmost clausestructural level (CP), here exemplified by V2, are not universally the most difficult area of syntax to attain. Lower structural levels, such as VP, may present equally severe or in fact more severe acquisition problems. As we have seen, mastery of nonfinite verb and object/complement placement in German (a syntactic phenomenon involving the VP domain), and mastery of transitive particle verb constructions in Swedish (equally a syntactic phenomenon involving the VP domain) both lag behind the acquisition of V2. Even in the interlanguage grammars of advanced learners, we have found nontarget parameter settings (DP-Prt) or residual optionality (DP-Prt and Prt-DP) in the domain of VP.

Compared to other studies of nonnative Swedish and German syntax, the developmental routes with respect to the same target language thus vary for learners with typologically distinct L1s: Whereas some learners (L1 Finnish, Romance, Turkish, Korean, English, etc.) may have problems in the highest clausal domain (e.g., V2), native speakers of Swedish learning German and native speakers of German learning Swedish do not. Therefore, the C-domain cannot be vulnerable per se (contra e.g., Bhatt and Hancin-Bhatt (2002), Platzack (2001)), and the I- and V-domains cannot be invulnerable per se (again contra Platzack (2001)). Moreover, acquiring the targetlike settings for the C-domain is not developmentally dependent on targetlike lower domains having been acquired first (contra e.g., Vainikka and Young-Scholten (1994; 1996a; 1996b)).

I therefore believe that theories of acquisition that postulate the existence of universal developmental paths or of universally vulnerable (and universally invulnerable) syntactic domains are on the wrong track. I suggest that we are better advised to adopt a theory of acquisition that allows us to differentiate L2 developmental routes, a theory that in fact predicts divergent L2 developmental routes to the same target language for groups of learners with typologically distinct L1s - in short, a theory that assumes full transfer of the L1 syntax in nonnative language acquisition (e.g., Schwartz and Sprouse (1994; 1996)).

\section{ACKNOWLEDGMENTS}

This work was supported by grant 142-2001-6286 from the Swedish Research Council (Vetenskapsrådet). I thank the Language Acquisition editors and three anonymous reviewers for their positive comments and helpful suggestions and Christer Platzack for valuable discussions. 


\section{REFERENCES}

Bhatt, R. M. and B. Hancin-Bhatt (2002) "Structural Minimality, CP and the Initial State in Second Language Acquisition," Second Language Research 18, 348-392.

Bohnacker, U. (2003) "Residual Word Order Problems in Advanced Adult L2 Swedish and German," in L.-O. Delsing, C. Falk, G. Josefsson, and H. Á. Sigurðsson, eds., Grammar in Focus: Festschrift for Christer Platzack 18 November 2003, Vol. 2, Wallin and Dalholm, Lund, Sweden.

Bohnacker, U. (2004) "Is V2 Really That Hard to Acquire for Second Language Learners? On Current Universalist L2 Claims and Their Empirical Underpinnings," Working Papers in Scandinavian Syntax 74, 43-79.

Bohnacker, U. (2005) "Nonnative Acquisition of Verb Second: On the Empirical Underpinnings of Universal L2 Claims," in M. den Dikken and C. Tortora, eds., The Function of Function Words and Functional Categories, John Benjamins, Amsterdam, The Netherlands.

Bohnacker, U. (2006a) "Developmental Sequences and (In)vulnerable Domains in German Interlanguage Syntax," in A. Belletti, E. Bennati, C. Chesi, E. DiDomenico, and I. Ferrari, eds., Language Acquisition and Development: Proceedings of GALA 2005, Cambridge Scholars Press, Cambridge, England.

Bohnacker, U. (2006b) "When Swedes Begin to Learn German: From V2 to V2," Second Language Research 22, 443-486.

Bolander, M. (1988) "Nu ja hoppas inte så mycke: Om inversion och placering av negation och adverb i svenska som andraspråk [Now I hope not so much: On inversion and the placement of negation and adverbs in Swedish as a second language]," in K. Hyltenstam and I. Lindberg, eds., Första symposiet om svenska som andraspråk, Vol. 1: Föredrag om språk, språkinlärning och interaktion, Centrum för tvåspråkighetsforskning, Stockholm University, Stockholm, Sweden.

Bolander, M. (1989) "Prefabs, Patterns and Rules in Interaction? Formulaic Speech in Adult Learners' L2 Swedish,” in K. Hyltenstam and L. K. Obler, eds., Bilingualism Across the Lifespan: Aspects of Acquisition, Maturity and Loss, Cambridge University Press, Cambridge, England.

Booij, G. (1990) "The Boundary Between Morphology and Syntax: Separable Complex Verbs in Dutch," Yearbook of Morphology 3, 45-63.

Brandt, M., M. Reis, I. Rosengren, and I. Zimmermann (1992) "Satztyp, Satzmodus und Illokution," in I. Rosengren, ed., Satz und Illokution, Vol. 2, Max Niemeyer, Tübingen, Germany.

Cardinaletti, A. and M. Starke (1995) "Deficient Pronouns: A View from Germanic: A Study in the Unified Description of Germanic and Romance," in M. Starke, E. Haeberli and C. Laenzlinger, eds., Geneva Generative Working Papers 3, 22-49.

Chomsky, N. (1957) Syntactic Structures, Mouton, The Hague.

Chomsky, N. (1993) "A Minimalist Program for Linguistic Theory," in K. Hale and S. J. Keyser, eds., The View from Building 20: Essays in Linguistics in Honor of Sylvain Bromberger, MIT Press, Cambridge, Massachusetts.

Chomsky, N. (1995) The Minimalist Program, MIT Press, Cambridge, Massachusetts.

Clahsen, H. (1990/1991) "Constraints on Parameter Setting: A Grammatical Analysis of Some Acquisition Stages in German Child Language," Language Acquisition 1, 361-391.

Clahsen, H., J. M. Meisel, and M. Pienemann (1983) Deutsch als Zweitsprache: Der Spracherwerb ausländischer Arbeiter, Narr, Tübingen, Germany.

Clahsen, H. and P. Muysken (1986) "The Availability of Universal Grammar to Adult and Child Learners: A Study of the Acquisition of German Word Order," Second Language Research 2, 93-119.

Clahsen, H., M. Penke, and T. Parodi (1993/1994) "Functional Categories in Early Child German," Language Acquisition 3, 395-429.

den Dikken, M. (1995) Particles: On the Syntax of Verb-Particle, Triadic, and Causative Constructions, Oxford University Press, Oxford, England. 
duPlessis, J., D. Solin, L. Travis, and L. White (1987) "UG or Not UG, That Is the Question: A Reply to Clahsen and Muysken," Second Language Research 3, 56-75.

Ejerhed, E. (1979) "Verb-partikel-konstruktionen i svenska: Syntaktiska och semantiska problem," in O. Josephson, H. Strand, and M. Westman, eds., Förhandlingar vid sammankomst för att dryfta frågor rörande svenskans beskrivning 11, Stockholm 1978, Department of Scandinavian Languages, Stockholm University, Stockholm, Sweden.

Ekerot, L.-J. (1995) Ordföljd, tempus, bestämdhet: Föreläsningar om svenska som andraspråk, Gleerups, Malmö, Sweden.

Emonds, J. (1972) "Evidence That Indirect Object Movement Is a Structure Preserving Rule," Foundations of Language 8, 546-561.

Eubank, L. (1993/1994) "On the Transfer of Parametric Values in L2 Development," Language Acquisition 3, 183-208.

Gärtner, H.-M. and M. Steinbach (2000) "What Do Reduced Pronominals Reveal About the Syntax of Dutch and German?," Linguistics in Potsdam 9.

Grewendorf, G. (1988) Aspekte der deutschen Syntax, Narr, Tübingen, Germany.

Grewendorf, G. (1990) "Verbbewegung und Negation im Deutschen," Groninger Arbeiten zur Germanistischen Linguistik 30, 57-125.

Grewendorf, G., F. Hamm, and W. Sternefeld (1987) Sprachliches Wissen. Eine Einführung in moderne Theorien der grammatischen Beschreibung, Suhrkamp, Frankfurt, Germany.

Haegeman, L. and J. Guéron (1999) English Grammar: A Generative Perspective, Blackwell, Oxford, England.

Haiden, M. (2001) "Verb Particle Constructions," in M. Everaert and H. van Riemsdijk, eds., The Syntax Companion [SynCom Case \#117], http://www.univ-lille3.fr/silex/equipe/haiden/particle/ case_117_vepa.htm

Haider, H. (1993) Deutsche Syntax-generativ. Vorstudien zur Theorie einer projektiven Grammatik, Narr, Tübingen, Germany.

Håkansson, G., M. Pienemann, and S. Sayehli (2002) "Transfer and Typological Proximity in the Context of Second Language Processing," Second Language Research 18, 250-273.

Hammarberg, B. and Å. Viberg (1977) "The Place-holder Constraint, Language Typology, and the Teaching of Swedish to Immigrants," Studia Linguistica 31, 106-163.

Hawkins, R. (2001) Second Language Syntax, Blackwell, Oxford, England.

Herslund, M. (1984) "Particles, Prefixes and Preposition Stranding," Topics in Danish syntax. Nydanske Studier og Almen Kommunikationsteori 14, Akademisk Forlag, Roskilde, Denmark.

Hoekstra, T. (1988) "Small Clause Results," Lingua 74, 101-139.

Hulk, A. and N. Müller (2000) "Bilingual First Language Acquisition at the Interface Between Syntax and Pragmatics," Bilingualism 3, 227-244.

Hulthén, L. (1947) Studier i jämförande nunordisk syntax, Vol. 2, Göteborgs högskolas årsskrift 53, Wettergren and Kerber, Gothenburg, Sweden.

Jackendoff, R. (2002) "English Particle Constructions, the Lexicon, and the Autonomy of Syntax," in N. Dehé, R. Jackendoff, A. McIntyre and S. Urban, eds., Verb-Particle Explorations, Mouton de Gruyter, Berlin, Germany.

Josefsson, G. (2003) "Input and Output," in G. Josefsson, C. Platzack and G. Håkansson, eds., The Acquisition of Swedish Grammar, John Benjamins, Amsterdam, The Netherlands.

Kayne, R. S. (1985) "Principles of Particle Constructions," in J. Guéron, H.-G. Obenauer, and J.-Y. Pollock, eds., Grammatical Representation, Foris, Dordrecht, The Netherlands.

Kayne, R. (1994) The Antisymmetry of Syntax, MIT Press, Cambridge, Massachusetts.

Koster, J. (1975) "Dutch as a SOV Language," in A. Kraak, ed., Linguistics in the Netherlands 1972-1973, Van Gorcum, Assen, The Netherlands.

Lüdeling, A. (1999) On Particle Verbs and Similar Constructions in German. [Arbeitspapiere des Sonderforschungsbereiches 340: Bericht 133], Doctoral dissertation, Universities of Stuttgart and Tübingen, Germany. 
Müller, N., ed. (2003) (In)vulnerable Domains in Multilingualism, John Benjamins, Amsterdam, The Netherlands.

Müller, N. and A. Hulk (2001) "Crosslinguistic Influence in Bilingual Language Acquisition: Italian and French as Recipient Languages," Bilingualism 4, 1-22.

Nauclér, K. (1995) “Att lära sig svenska som andraspråk," in E. Ahlsén and J. Allwood, eds., Språk i fokus, Studentlitteratur, Lund, Sweden.

Norén, K. (1996) Svenska Partikelverbs Semantik. Acta Universitatis Gothoburgensis, Gothenburg University, Gothenburg, Sweden.

Paul, H. (1959) Deutsche Grammatik, Vol. 3, Max Niemeyer, Halle, Germany (Original work published 1919).

Pienemann, M. (1998) Language Processing and Second Language Development: Processability Theory, John Benjamins, Amsterdam, The Netherlands.

Platzack, C. (1996) "The Initial Hypothesis of Syntax. A Minimalist Perspective on Language Acquisition and Attrition," in H. Clahsen, ed., Generative Perspectives on Language Acquisition, John Benjamins, Amsterdam, The Netherlands.

Platzack, C. (1998) Svenskans inre grammatik—det minimalistiska programmet: En introduktion till modern generativ grammatik, Studentlitteratur, Lund, Sweden.

Platzack, C. (2001) "The Vulnerable C-domain," Brain and Language 77, 364-377.

Platzack, C. (2003) “The Verb Phrase,” in G. Josefsson, C. Platzack, and G. Håkansson, eds., The Acquisition of Swedish Grammar, John Benjamins, Amsterdam, The Netherlands.

Radford, A. (1988a) "Small Children's Small Clauses," Transactions of the Philological Society 86, $1-43$.

Radford, A. (1988b) Transformational Grammar: A First Course, Cambridge University Press, Cambridge, England.

Riemsdijk, H. C. van (1978) A Case Study in Syntactic Markedness, Peter de Ridder, Lisse, The Netherlands.

Sawyer, J. (2001) "Bifurcating the Verb Particle Construction: Evidence From Child Language," Annual Review of Language Acquisition 1, 119-156.

Schwartz, B. and R. Sprouse (1994) "Word Order and Nominative Case in Nonnative Language Acquisition: A Longitudinal Study of L1 Turkish German Interlanguage," in T. Hoekstra and B. Schwartz, eds., Language Acquisition Studies in Generative Grammar, John Benjamins, Amsterdam, The Netherlands.

Schwartz, B. and R. Sprouse (1996) "L2 Cognitive States and the Full Transfer/Full Access Model," Second Language Research 12, 40-72.

Schwartz, B. D. and R. A. Sprouse (2000) "When Syntactic Theories Evolve: Consequences for L2 Acquisition Research," in J. Archibald, ed., Second Language Acquisition and Linguistic Theory, Blackwell, Oxford, England.

Schwartz, B. D. and S. Vikner (1989) "All Verb Second Clauses are CPs," Working Papers in Scandinavian Syntax 43, 27-49.

Svenonius, P. (1996) "The Optionality of Particle Shift," Working Papers in Scandinavian Syntax $57,47-75$.

Taraldsen, K. T. (1983) Parametric Variation in Phrase Structure: A Case Study, Tromsø University, Troms $\varnothing$, Norway.

Teleman, U. (1974) Manual för grammatisk beskrivning av talad och skriven svenska, Studentlitteratur, Lund, Sweden.

Teleman, U., S. Hellberg, and E. Andersson, eds. (1999a) Svenska Akademiens grammatik, Vol. 3: Fraser, NorstedtsOrdbok, Stockholm, Sweden.

Teleman, U., S. Hellberg, and E. Andersson, eds. (1999b) Svenska Akademiens grammatik, Vol. 4: Satser och meningar, NorstedtsOrdbok, Stockholm, Sweden.

Travis, L. de Mena (1984) Parameters and Effects of Word Order Variation, Doctoral dissertation, MIT, Cambridge, Massachusetts. 
Travis, L. de Mena (1991) "Parameters of Phrase Structure and Verb-Second Phenomena," in R. Freidin, ed., Principles and Parameters in Comparative Grammar, MIT, Cambridge, Massachusetts. Vainikka, A. and M. Young-Scholten (1994) "Direct Access to X' theory: Evidence From Korean and Turkish Adults Learning German," in T. Hoekstra and B. Schwartz, eds., Language Acquisition Studies in Generative Grammar, John Benjamins, Amsterdam, The Netherlands.

Vainikka, A. and M. Young-Scholten (1996a) "The Early Stages in Adult L2 Syntax: Additional Evidence From Romance Speakers," Second Language Research 12, 140-176.

Vainikka, A. and M. Young-Scholten (1996b) "Gradual Development of L2 Phrase Structure," Second Language Research 12, 7-39.

Viberg, Åke (1993) “Andraspråksinlärning i olika åldrar," in E. Cerú, ed., Svenska som andraspråk: Lärarbok 2, Natur och kultur \& Utbildningsradion, Stockholm, Sweden.

Vinka, M. (1999) "Predicative and Non-predicative Verb Particle Constructions," WCCFL 18 Proceedings, Cascadilla Press, Somerville, Massachusetts.

White, L. (1985) "The 'Pro-drop' Parameter in Adult Second Language Acquisition," Language Learning 35, 47-62.

Wurmbrand, S. (1998) "Heads or Phrases? Particles in Particular," in W. Kehrein and R. Wiese, eds., Phonology and Morphology of the Germanic Languages, Niemeyer, Tübingen, Germany.

Wurmbrand, S. (2000) "The Structure(s) of Particle Verbs," ms., McGill University, Montreal, Canada.

Zeller, J. (2001) Particle Verbs and Local Domains, John Benjamins, Amsterdam, The Netherlands.

Zifonun, G., L. Hoffmann, and B. Strecker (1997) Grammatik der deutschen Sprache. Schriften des Instituts für deutsche Sprache Vol. 7.2, Walter de Gruyter, Berlin, Germany.

Zwart, Jan-Wouter (1993) Dutch Syntax. A Minimalist Approach, Doctoral dissertation, University of Groningen, Groningen, The Netherlands.

Submitted 5 July 2005

Final version accepted 7 April 2006 
Copyright of Language Acquisition is the property of Lawrence Erlbaum Associates and its content may not be copied or emailed to multiple sites or posted to a listserv without the copyright holder's express written permission. However, users may print, download, or email articles for individual use. 